\title{
Homonegative attitides after Obergefell v. Hodges. Quasi-experimental evidence of anticipatory backlash abroad
}

\author{
Stuart J. Turnbull-Dugarte
}

December 2020

\begin{abstract}
Does the expansion of LGBT+ rights in the US affect mass attitudes towards sexual minorities abroad? Relying on a quasi-experiment presented by the as good as random exposure to news regarding the US's legalisation of same-sex marriage in the landmark US Supreme Court case - Obergefell vs Hodges - in Israel, I present an empirical test of the cross-national effect of LGBT+ rights advances in the US on mass attitudes abroad. Empirically, I rely on data from wave 7 of the European Social survey to show that legalising same-sex marriage engendered a popular backlash towards homosexuality amongst Israeli citizens and that this rise in homonegativity was greatest amongst women. In contrast to the domestic tolerance-inducing effects of policy feedback at home, this study shows that advances in domestic LGBT+ rights can trigger a negative response among citizens beyond the confines of a state's borders.
\end{abstract}

Keywords: same-sex marriage, backlash, LGBT+ politics, Obergefell v. Hodges, Israel

\footnotetext{
*University of Southampton. Email: S.Turnbull-Dugarte@Soton.ac.uk

${ }^{\dagger}$ An earlier iteration of this paper benefited from the feedback of participants at the University of Montre al Chair in Electoral Democracy Seminar and the University of Southampton Politics IR research seminar. Special thanks to Jessica Smith, Viktor Valgardsson, Ben Saunders, Philip Jones, Ruth Dassonneville \& Joshua Townsley for additional comments. I am also very grateful to Dan Devine for helping me with a LaTeX coding problem.
} 


\section{Introduction}

In 2015 the United States Supreme Court (SCOTUS) ruled in a landmark case for civil rights that access to same-sex marriage $(\mathrm{SSM})^{1}$ was protected by the US Constitution's Due Process and Equal Protection clauses. SCOTUS' ruling in the case-Obergefell $v$. Hodges - was praised by liberals as a watershed moment for lesbian, gay and bisexual individuals in which SSM was established as the law of the land in the US' fifty states. Whilst a body of work has assessed how the expansion of LGBT+ rights, such as SSM, influences domestic attitudes towards sexual minorities (Abou-Chadi et al., 2019; Bishin et al., 2016; Flores et al., 2016; Kreitzer et al., 2014), we still do not know if the expansion can engender cross-national contagion. Does the progressive expansion of LGBT+ rights in the US affect mass attitudes towards sexual minorities abroad?

In this letter, I argue that the expansion of SSM rights in the US can signal to the citizens of other states that LGBT+ rights are growing and that conventional, heteronormative institutions are being liberalised to be more inclusive of sexual minorities. Domestically, contemporary research points to the norm-shaping role of SSM reform leading to a positive feedback loop that increases support for homosexuality (Abou-Chadi et al., 2019; Flores et al., 2016; Kreitzer et al., 2014) rather than the backlash effects found in the past (Donovan et al., 2013; Klarman, 2012). Changes to established, and largely religiously enshrined institutions, however, may be perceived by citizens in other countries as a threat to established norms (Ayoub, 2014; Weiss, 2013). An emerging body of work highlights that the expansion of LGBT+ rights in the West has led to the emergence of an anticipatory backlash that sparks pre-emptive action aimed and protecting heteronormative society from the international contagion of pro-LGBT+ liberalism (Currier et al., 2020; Mos, 2020; Nuñez-Mietz et al., 2017).

Empirically, I present evidence from a quasi-experiment in Israel. Exploiting the as

\footnotetext{
${ }^{1}$ Same-sex marriage is, arguably, an inaccurate term given that the reform normally facilitates the recognition of marriages between individuals of the same legal gender. I use the term same-sex marriage (SSM) in line with its prevalent use in the literature.
} 
good as random exposure to the widely reported global news story regarding the Obergefell $v$. Hodges ruling, I rely on the "unexpected event during survey fieldwork" approach (Muñoz et al., 2020) ${ }^{2}$ to provide causal evidence that exposure to the SCOTUS decision had a significant negative effect on attitudes, particularly among women, towards homosexuality.

The contribution of this empirical analysis are fourfold. First, it provides the first (quasi-)experimental analysis that supports the anticipatory backlash thesis. Second, whilst the literature on anticipatory backlash focuses on the responses of countermovements and elite responses, the analysis presented here looks at attitudinal responses on the ground and asks how everyday citizens respond. The results show that the anticipatory backlash observed amongst elites and movements appears to also be reflected amongst the general public. Third, the analysis speaks to the concrete literature on the effects of same-sex marriage reforms in the US (Donovan et al., 2013; Flores et al., 2016; Kreitzer et al., 2014). Moving beyond the domestic-orientated lens of recent research that highlights the positive and tolerance-driving effects of the same, the results presented here demonstrate that the US' legalisation of SSM has engendered unintended consequential effects for the wider LGBT+ community beyond the US' borders. Fourth, it contributes evidence to the growing body of work that highlights the transnational effect of domestically salient political events. In the same way that research points towards the (unexpected) victory of Donald Trump having a cross-border effect on individuals' prejudices towards immigration (Giani et al., 2019) and the Brexit vote in the UK altering electoral choices in Spain (Delis et al., 2020), I show that the US' legalisation of SSM has a cross-border effect on prejudices towards homosexuality.

\footnotetext{
${ }^{2}$ This is an increasingly applied means of causal identification. See, for example, Giani (2020)'s analysis of the causal impact of terrorist attacks on security fears.
} 


\section{Effects of same-sex marriage reform}

Comparative evidence from both the US and Europe indicates that policy implementations can trigger a policy feedback mechanism (Soss et al., 2007) that engenders a change in public opinion. Empirically, we observe positive policy feedback effects in the case of LGBT+ rights. In Europe, Abou-Chadi et al. (2019) show that those states that legitimise same-couples by providing them with access to the same statesponsored recognition of their partners as opposite-sex couples leads to an increase in public acceptance towards homosexuals within these states. In the US, and despite previous evidence of backlash (Klarman, 2012), Flores et al. (2016) rely on panel data from the American National Election study to show that the expansion of SSM among a number of US states increased popular tolerance tolerance towards lesbian, gay and bisexual individuals. Both the work of Flores et al. (2016) and Abou-Chadi et al. (2019) theorise that the positive effect of the introduction of SSM is the product of the norm-altering role of introducing SSM. When the state legitimises same-sex couples by placing them, institutionally, on an equal footing with opposite-sex couples, this establishes a new social norm in which sexual minorities are considered part of the societal in-group. These studies, along with others in both the US (Bishin et al., 2016; Donovan et al., 2013; Kreitzer et al., 2014) and elsewhere (Hooghe et al., 2013; Takács et al., 2011), focus on the how domestic reforms in favour of SSM affected mass attitudes.

A body of research suggests, however, that the expansion of LGBT+ rights in certain states triggers responses in others. Paternotte et al., 2013, for example, highlight the role of transnational learning as a means of driving congruence in LGBT+ rights across state lines as new norms are established (Kollman, 2013). Importantly, the effects of the "international dimensions" of LGBT+ rights (Mos, 2020), are not always positive. Observing the steady and progressive advances of LGBT+ rights outside of the state can increase the perceived threat that LGBT+ rights advances represent to conventional norms at home in those states that have not yet liberalised on the question of LGBT+ 
rights (Ayoub, 2014; O’Dwyer, 2012). This threat perception (conventional marriage as being undermined) and threat identification (global advances in institutional acceptance of LGBT+) triggers actors to take anticipatory action.

Weiss (2013) was one of the first to highlight the role of extra-state advancements in LGBT+ rights as a catalyst for "anticpatory countermovements" and popular backlash against LGBT+ rights despite the absence of viable domestic demand for change. Rather than domestic factors, Weiss finds that the advancements of social movements advocating for LGBT+ results elsewhere led to increases in the threat perception of the same occurring in South East Asian states. Viewing Western advancements in LGBT+ rights as evidence of the "teleologically unavoidable and existential threat" (Weiss, 2013) presented to the norms of states in South Eastern Asia, these states pre-emptively applied regressive changes that increased the institutionalised discrimination against sexual minorities.

Of note is that the evidence of anticipatory backlash is not unique to country cases beyond the veneer of the "West". Mos (2020), for example, shows that there is a strong correlation between countries' expansion of SSM and pre-emptive efforts by certain states to defend against the same in Europe. Looking at European states' recognition of SSM laws between 2001 and 2018, Mos finds that the more states legalised SSM, the more neighbouring states reformed their constitutions to protectively enshrine a heteronormative definition of marriage between one man and one woman. In other words, SSM reforms amongst certain EU member states engendered a contagious rejection on SSM laws amongst their neighbours. In relation to the specific case of the US' 2015 SSM ruling, there is evidence that this has served as a legitimising tool for opponents of LGBT+ rights in Indonesia, for example, to engage in anticipatory backlash (Wijaya, 2020)

Increasing evidence points towards the importance of the "international dimension" (Mos, 2020) of LGBT+ reforms and norm transformation. Whilst the literature on domestic change points towards SSM having a positive effect in that it drives up support 
for sexual minorities, the evidence seeking to assess cross-country contagion suggests that the effect of advances in SSM laws beyond the confines of the state can induce negative reactions among political activists and elites. There is yet to be an empirical test, however, regarding the potential backlash-inducing effect of SSM advances abroad on mass attitudes. It remains unclear whether the anticipatory backlash among policy-makers reflects a general rejection of the threat of international norms among the citizens.

Testing the effect of the US' federal legalisation of SSM on mass attitudes towards homosexuality in countries that have not yet legalised SSM, I formulate two alternative hypotheses. First, and in line with the norm-diffusing argument observed domestically (Abou-Chadi et al., 2019; Flores et al., 2016), the ruling will increase tolerance and acceptability of homosexuals (H1). Second, we might expect the US' legalisation of SSM to result in increased opposition towards homosexuality $(\mathbf{H} 2)$, as the decision signals the potential threat advances in LGBT+ rights pose to established norms at home (Ayoub, 2014; Mos, 2020; Weiss, 2013).

Finally, a rich body of research highlights the divergent attitudes towards issues of social morality, including LGBT+ rights issues, between men and women. Empirically, a traditional gender gap has been observed in a number of states and demonstrates that women, on average, harbour more conservative views in relation men (Barisione, 2014; Inglehart et al., 2003). This increased conservatism, particularly in matters of conscience and morality (Campbell et al., 2015; Shapiro et al., 1986) is rooted in women's increased religiosity vis-à-vis men (Emmenneger Patrick, 2014). In a number of societies, however, this gender gap has been reversed with increasing secularism and a rise in labour market participation among women leading to the establishment of a modern gender gap with increased support for liberal policy positions compared to men (Abendschoen et al., 2014; Giger, 2009; Inglehart et al., 2003), and this is also reflected in attitudes towards LGBT+ rights (Dotti Sani et al., 2020). ${ }^{3}$ There is, therefore,

\footnotetext{
${ }^{3}$ Even among societies with a "modern" gender gap like the UK, there is evidence that Conservativevoting women still place a higher premium on authoritarian policies like support for censorship when
} 
a strong expectation for asymmetric responses to treatment among men and women (H3). Given the traditional gender gap is observed to continue in those states with a strong religiosity (Abendschoen et al., 2014) and the significant role of the Judaism in Israeli society, we might expect a traditional (negative) gap to magnify the effect of treatment amongst women.

\section{Analytical strategy}

\subsection{Research design}

To establish a link between the US' national legalisation of SSM and attitudes towards homosexuality beyond the confines of the US, I rely on data provided by wave 7 of the ESS in Israel. The causal identification strategy relies on the "unexpected event during survey" fieldwork approach detailed by Muñoz et al. (2020). The fieldwork of the ESS in Israel took place between May and December 2015. The US supreme court ruling, announced on June 26th 2015, therefore fell in the middle of this fieldwork. Whilst the ESS took place across a number of countries, no other country's fieldwork coincided directly with the ruling and provided responses on either side of the exposure threshold.

Exploiting the unexpected nature of the court's decision during the survey fieldwork and the quasi-random nature of exposure, provides a setting in which one can causally identify the effect of the ruling on different outcomes (Muñoz et al., 2020). Given the federal legalisation of SSM was brought about by the judiciary (as opposed to the legislature) adds an additional level of exogeneity to the reform. ${ }^{4}$ Since the fieldwork of the ESS in Israel took place over a number of months, I constrain the temporal doing so is done to uphold "moral values" (Campbell et al., 2015).

${ }^{4}$ As the case of many salient SCOTUS rulings, the decision was the result of a 5-4 split on the court. The outcome could not have been predicted. Importantly, SSM reform via the judiciary reduces the predictability of policy change that would be the case should legalisation been the result of policymakers responding to shifting voters demands. 


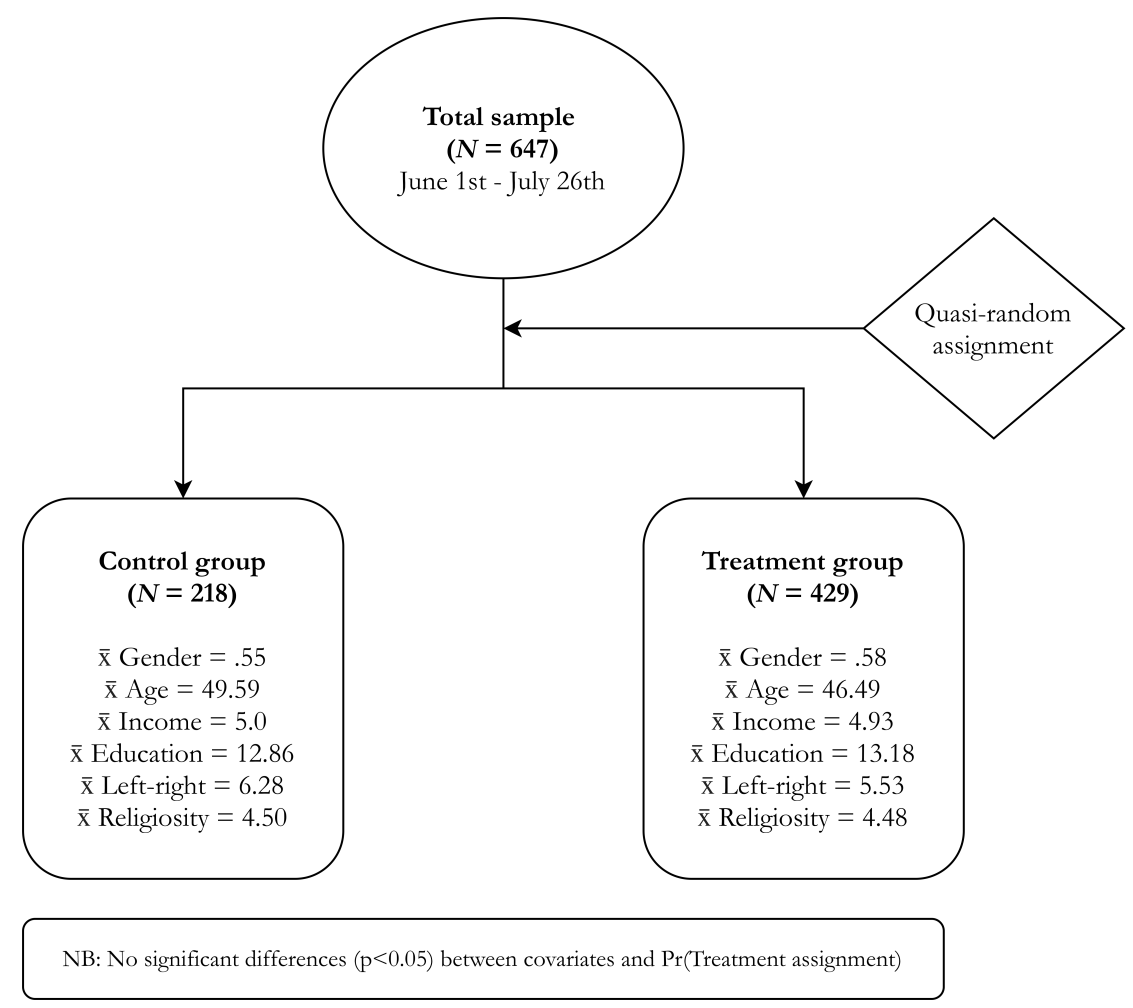

Figure 1: Treatment assignment \& balance

horizon of the sample to a bandwidth of \pm 30 days relative to treatment. Doing so aids the isolation of the independent causal effect of random assignment on our outcome of interest but comes at the cost of fewer observations and less statistical power. Given the causal motivations of the contribution I seek to make, I opt for an approach that favours identification. Alternative cut-off dates, presented in the appendix (A4), do not condition the primary results.

One of the potential threats to causal identification in using the applied approach is violation of the ignorability assumption (Muñoz et al., 2020). To test for this, I test for covariate balance across the population of individuals in each of the treatment conditions. Figure 1 displays the distribution of ESS respondents who were interviewed before (control) and after (treatment) the court ruling and the mean covariate values of each group. Whilst survey sampling can lead to imbalance (Muñoz et al., 2020), testing for this shows that both groups are statistically symmetrical on all covariates of 
interest resulting in the only discernible difference between them being their exposure to treatment. The ignorability assumption also requires that estimates not be biased by attrition. Testing for asymmetric attrition rates shows that treatment assignment does not condition a respondents' willingness to provide a response to the main outcome measures (Appendix Figure A5).

An essential assumption that underpins the "unexpected event" causal identification strategy is that the event itself was salient and one that survey respondents randomly assigned to treatment were likely to be aware of. To test for the level of mass interest in the ruling, I assess issue saliency by relying on Google Trends data for Israel. Figure 2 reports the relative popularity of searches in Israel for "gay marriage" and "samesex marriage". All of these terms observed a notable spike in interest on the date of treatment. This points towards the SCOTUS ruling being an event of interest among citizens and signals the relative salience of the events that took place in the US. Of note is that we can observe that the referendum on SSM that took place in Ireland in May played less of a role in spiking interest in SSM.

\subsection{Outcome variable}

To capture attitudes towards homosexuality, I rely on responses to the question "To what extent do you agree or disagree with each of the following statements: Gay men and lesbians should be free to live their own life as they wish?". Respondents can indicate their attitudes on a five-point scale from "strongly agree" to "strongly disagree". For simplicity, I dichotomise responses to capture those who either strongly agree or agree that homosexuals should be free to live as they wish (1); and those who do not $(0) .{ }^{5}$ Wave 7 of the ESS provides no other survey instrument capturing attitudes towards homosexuals, sexual minorities or LGBT+ rights.

\footnotetext{
${ }^{5}$ This is for ease of comparison with the different placebo tests which are indicated using various scales. Models using the 5-point range rather than the dichotomous operationalisation are reported in appendix Table A5 (OLS) and A6 (ordinal logit). The results remain unchanged.
} 


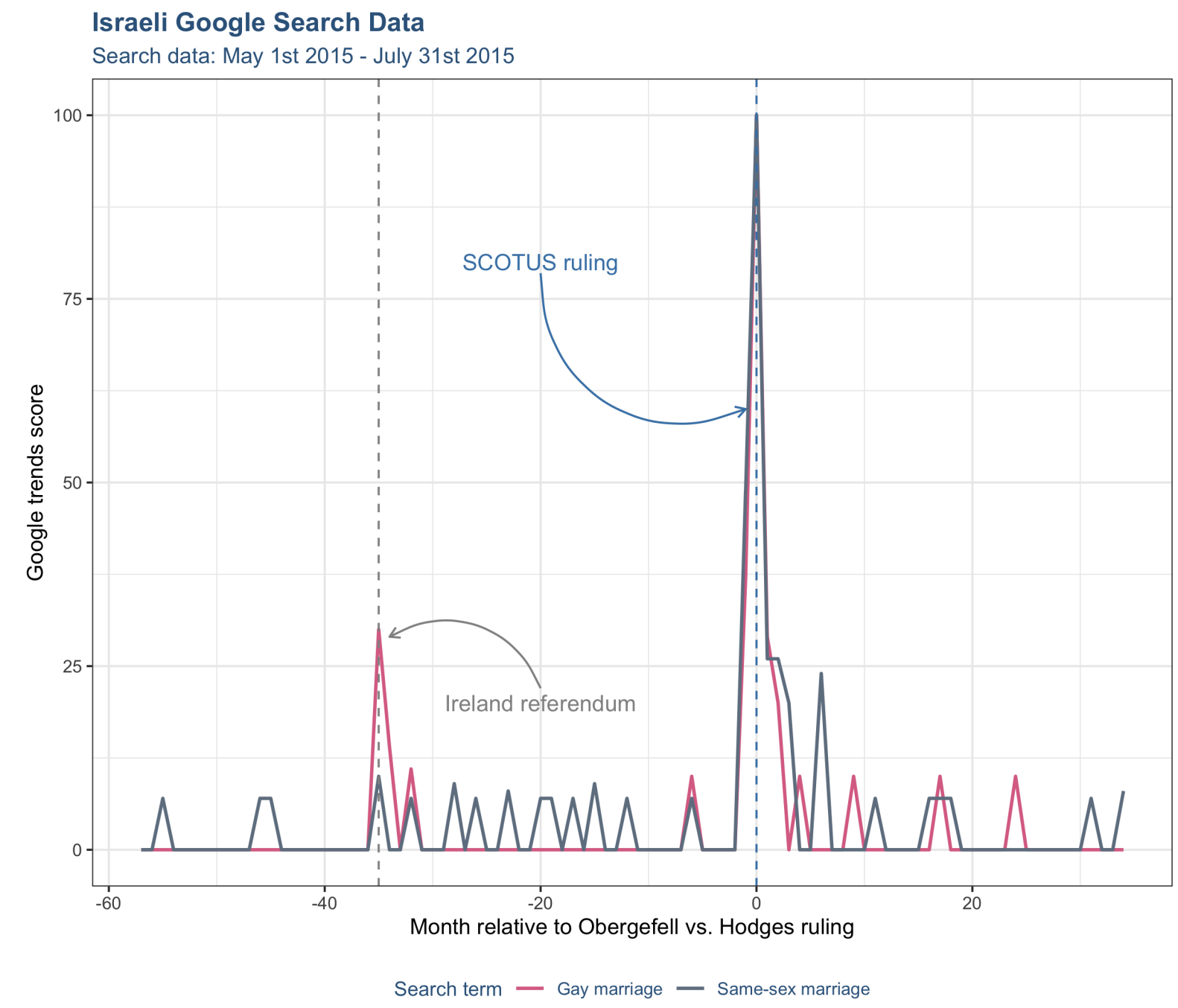

Figure 2: Popular interest in the SCOTUS ruling 


\subsection{Explanatory variable}

The primary explanatory variable is treatment assignment. Those interviewed on or after the date of the ruling (June 26th) belong to the treatment group $(N=429)$. Those interviewed before the court's ruling belong to control $(N=218)$. As detailed in Figure 1 the distribution of covariates across the two groups are symmetrical.

\subsection{Model}

Our estimand of interest is the intent-to-treat (ITT) ${ }^{6}$ effect of the (naturally occurring) random assignment to different treatment conditions. The ITT is the relevant estimand as there is no measure of treatment receipt - i.e. the estimand compares individuals who were (naturally) assigned to different treatment conditions rather than if they were actually exposed to the ruling news. The model specification is summarised in the basic model in which $\beta_{1}$ Treatment $_{i}$ is the covariate-adjusted ITT, $\gamma X_{i}$ is a vector of individual covariates and $\epsilon_{i}$ is the error term:

$$
Y_{i}=\alpha+\beta_{1} \text { Treatment }_{i}+\gamma X_{i}+\epsilon_{i}
$$

Given the binary outcome variable, the estimation reports the output of logistic regression models (OLS replications do not condition the results) estimating the effect of treatment on attitudes towards homosexuality adjusting the ITT by controlling for a vector of covariates including: gender, age, income, education and ideological placement on the left-right scale ${ }^{7}$. In order to test H3 I first include a multiplicative interac-

\footnotetext{
${ }^{6}$ The ITT is summarised as: $\operatorname{ITT}_{Y}=\frac{1}{N} \sum_{i=1}^{N} Y_{i}(z=1)-\frac{1}{N} \sum_{i=1}^{N} Y_{i}(z=0)$ where $Y_{i}(z=1)$ is the potential outcome for individual $i$ under treatment assignment and $Y_{i}(z=0)$ is the potential outcome for $i$ under assignment to control. The ITT is the appropriate estimand in this instance given the absence of a compliance measure.

${ }^{7}$ Models using a wider battery of potential controls such as self-reported religiosity are reported in
} 
Table 1: ITT effect on public acceptance of homosexuality

\begin{tabular}{|c|c|c|c|c|}
\hline$X$ & $\begin{array}{c}\text { (1) } \\
\text { Full sample }\end{array}$ & $\begin{array}{c}\text { (2) } \\
\text { Full sample }\end{array}$ & $\begin{array}{c}\text { (3) } \\
\text { Male subsample }\end{array}$ & $\begin{array}{c}\text { (4) } \\
\text { Female subsample }\end{array}$ \\
\hline Treatment & $\begin{array}{l}-0.34^{*} \\
(0.20)\end{array}$ & $\begin{array}{c}0.42 \\
(0.29)\end{array}$ & $\begin{array}{c}0.39 \\
(0.30)\end{array}$ & $\begin{array}{c}-1.02^{* * *} \\
(0.28)\end{array}$ \\
\hline Sex (female) & $\begin{array}{c}0.12 \\
(0.19)\end{array}$ & $\begin{array}{l}1.10^{* * *} \\
(0.34)\end{array}$ & & \\
\hline Treatment ${ }^{*}$ Sex & & $\begin{array}{c}-1.49^{* * *} \\
(0.41)\end{array}$ & & \\
\hline Age & $\begin{array}{l}-0.01^{* *} \\
(0.00)\end{array}$ & $\begin{array}{l}-0.01^{* *} \\
(0.00)\end{array}$ & $\begin{array}{l}-0.01 \\
(0.01)\end{array}$ & $\begin{array}{l}-0.01 \\
(0.01)\end{array}$ \\
\hline Left-right position & $\begin{array}{c}-0.14^{* * *} \\
(0.04)\end{array}$ & $\begin{array}{c}-0.14^{* * *} \\
(0.04)\end{array}$ & $\begin{array}{c}-0.17^{* * * *} \\
(0.06)\end{array}$ & $\begin{array}{l}-0.11^{* *} \\
(0.05)\end{array}$ \\
\hline Income & $\begin{array}{l}0.14^{* * *} \\
(0.05)\end{array}$ & $\begin{array}{l}0.15^{* * *} \\
(0.05)\end{array}$ & $\begin{array}{l}0.15^{* *} \\
(0.07)\end{array}$ & $\begin{array}{l}0.17^{* *} \\
(0.07)\end{array}$ \\
\hline Education & $\begin{array}{l}0.11^{* * *} \\
(0.03)\end{array}$ & $\begin{array}{l}0.11^{* * *} \\
(0.03)\end{array}$ & $\begin{array}{l}0.17^{* * *} \\
(0.05)\end{array}$ & $\begin{array}{l}0.07^{* *} \\
(0.04)\end{array}$ \\
\hline Constant & $\begin{array}{l}-0.13 \\
(0.60)\end{array}$ & $\begin{array}{l}-0.71 \\
(0.62)\end{array}$ & $\begin{array}{l}-1.12 \\
(0.93)\end{array}$ & $\begin{array}{c}0.55 \\
(0.75)\end{array}$ \\
\hline Observations & 647 & 647 & 279 & 368 \\
\hline
\end{tabular}

tion term between sex and treatment, and also rely on sex-based stratified subsamples. I apply the sampling weights provided by the ESS. Estimations without weighting do not condition the point-estimate of the ITT (Appendix Figure A7).

\section{Empirical results}

Table 1 reports the effect of exposure to the Obergefell $v$. Hodges ruling on popular attitudes towards homosexuality amongst Isreali citizens.

As expected by the anticipatory backlash thesis (H2), the results demonstrate that

the appendix. Across these specifications, the results remain constant - see Appendix Table A3 and A4. These variables are not included in the primary analysis given the potential role of post-treatment bias. Given, for example the theories argument that viewing SSM reforms taking place abroad can trigger increase threat perception, it is possible that this threat against heteronormaive norms might also trigger support increases in religiosity 
ITT on $\operatorname{Pr}$ (Accepting of homosexuality)
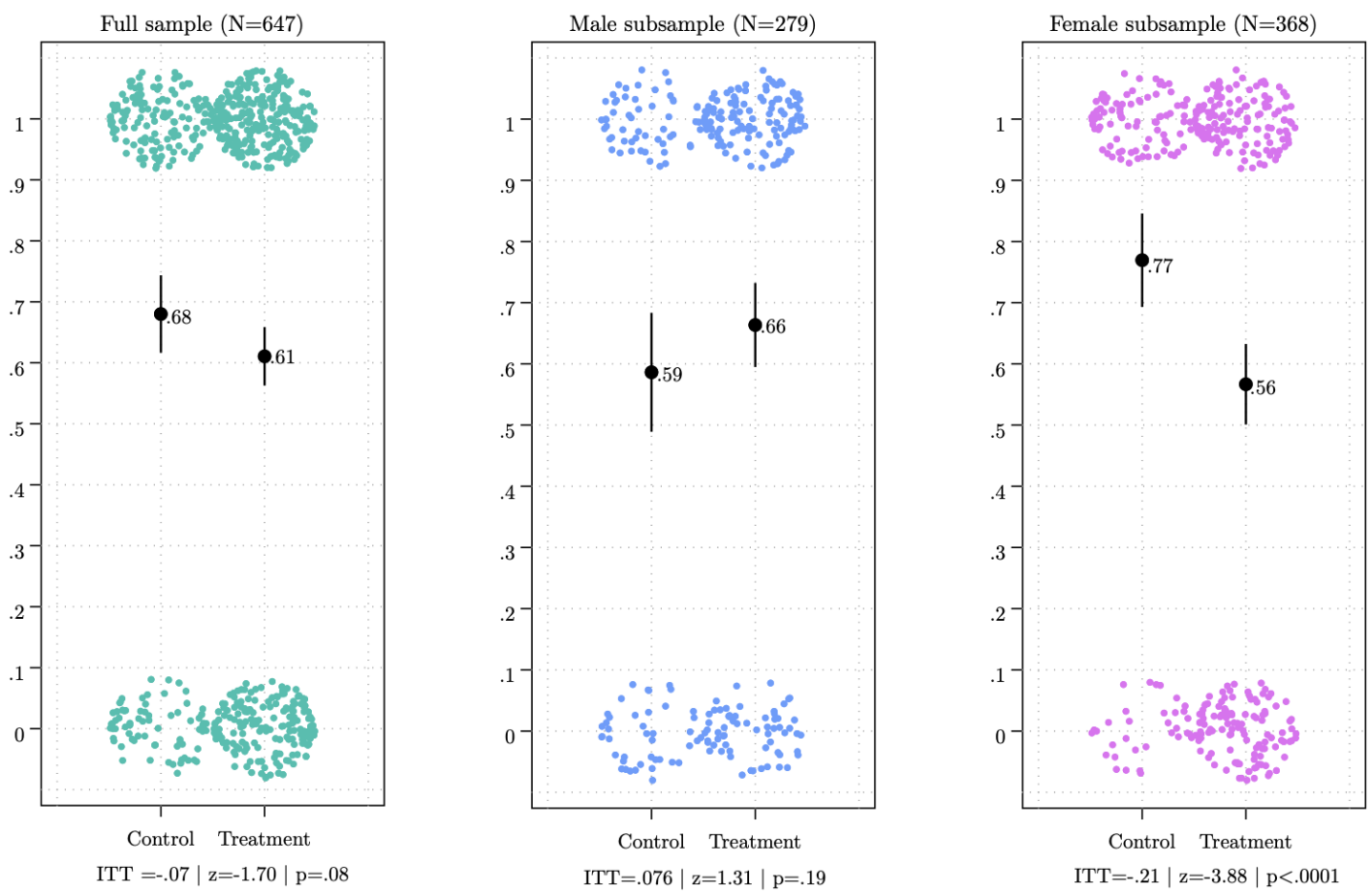

Figure 3: ITT effect on full and sex-based subsamples

those interviewed immediately after the ruling were significantly less likely to hold supportive views on homosexuality compared to those in the control group. Given our reliance on logistic regression, Figure 3 reports the group-based mean probability of holding an accepting view homosexuality among the control and treatment groups for ease of interpretation. The left-hand panel displays the estimates from Model 1 in Table 1. The predicted probability of holding tolerant views towards homosexuality in the control condition is 0.68 whereas it is .61 in the case of treatment. The pointestimate of the ITT effect is non-trivial at 7 percentage-points and significant $(p=.08)$. In substantive terms, an effect of 7 percentage-points equates to a fall of $10.3 \%$ vis-à-vis the control group mean (14.7\% of a standard deviation).

The on average effect of treatment across the wider population, however, masks significant variation between the sexes (H3). Model 2 includes a multiplicative interaction term between treatment assignment and the sex of respondents. The model reports a null effect in the case of men and a sizable and substantive effect for women. These 
asymmetric treatment effects are replicated in subsample regressions of men (Model 3) and women (Model 4). As in the case of the main model, the predicted margins of the sex-based subsamples are illustrated in Figure 3 for ease of interpretation.

The central panel shows the effect on men. Comparing attitudes towards homosexuality among men in the two treatment conditions reveals no difference of substance. The estimated ITT between the control group probability (.59) and that of the treatment group (.66), whilst large at 7.6 percentage-points, remains statistically indistinguishable from zero $(p=.19)$. In the case of women, however, there is a substantive and identifiable effect. Women in Israel interviewed immediately after Obegefell vs Hodges became, on average, 21 percentage-points $(p<.0001)$ less likely to hold liberal views on homosexuality in comparison to those in the control group. In terms of the effect magnitude, a 21-point decrease under treatment assignment is substantive, equating to a fall of just under a third (27\%) relative to the control group mean or $46.4 \%$ of a standard deviation.

\subsection{Robustness tests \& conditionality}

To validate the link between treatment and the main outcome variable, I present a number of sensitivity and robustness tests. First I demonstrate that the ruling had no effect on a variety of attitudinal placebos that have no theoretical connection to treatment assignment. Figure 4 reports the effect of treatment on the main outcome as well as three different placebos: (i) preferences regarding economic redistribution, (ii) attitudes towards immigration, and (iii) perceptions of the economic performance of the country. Given the asymmetric gender effects observed for the main outcome, I test for the same on the placebos. Should the negative effect of the Obergefell $v$. Hodges occur because it engenders a specific backlash against the progress of LGBT+ rights, we should not observe any effects on our placebo measures. The results, as illustrated in Figure 4, support this. There is no identifiable change in any of the placebo measures 

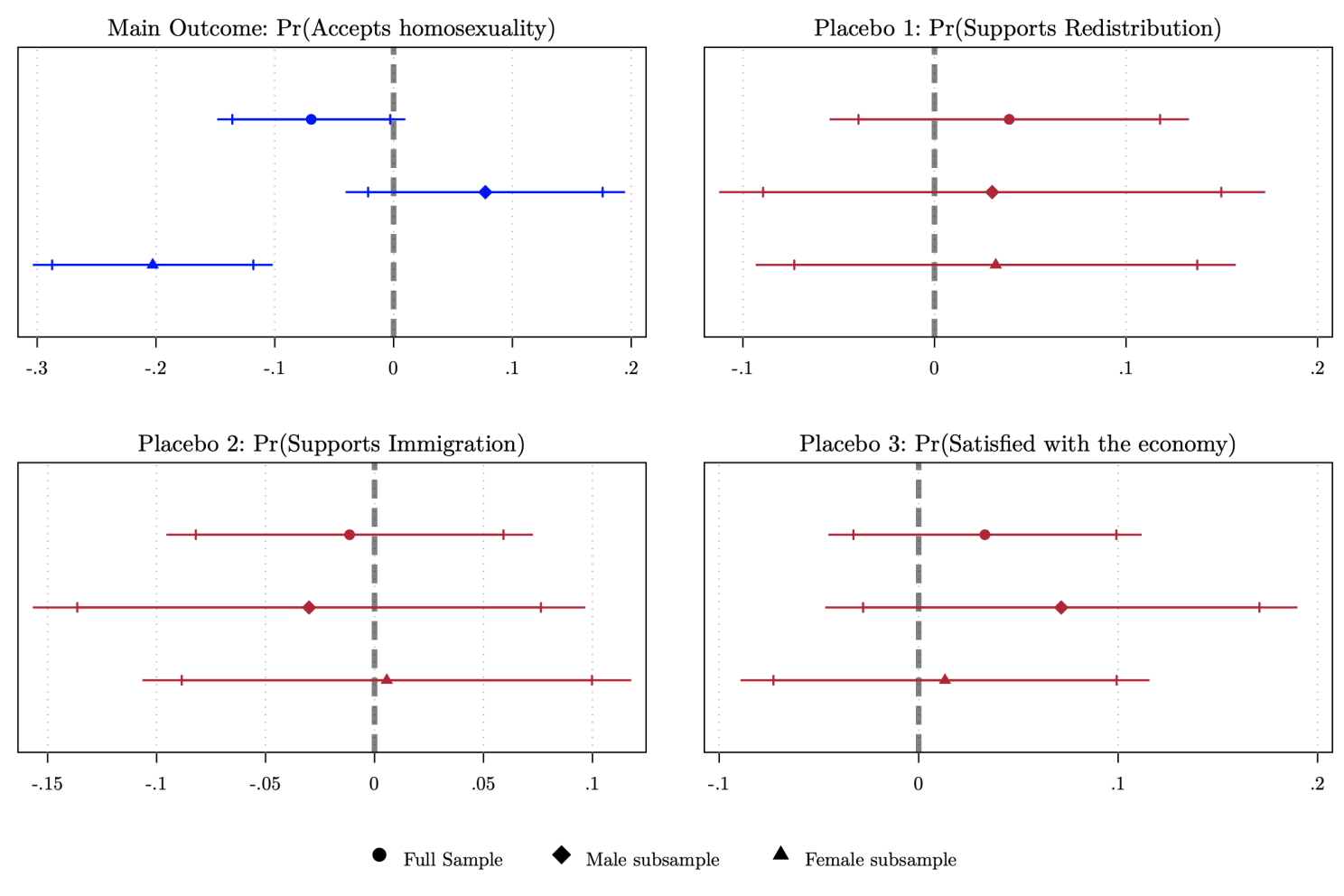

Figure 4: Placebo models

among the full sample or amongst the sex-based subsamples.

Second, one challenge of the "unexpected event" approach is that the effect associated with the quasi-random treatment assignment is spurious and the result of pure chance. To rule out this possibility, I replicate the analysis by randomly varying the date of treatment assignment and modelling its effect on the dependent variable. Figure 5 shows the output of 1,000 different permutations using randomly assigned treatment dates. The vertical lines represent the observed beta coefficient for each of the model samples reported in Figure 3. Across all three models, the coefficient observed in the case of the real treatment date are larger than the majority of those produced by the placebo dates produced by the permutations, particularly in the case of the female subsample.

Thirdly, I also show that the increase in homonegative attitudes is not the result of time trends via two empirical approaches. First, and as recommended by Muñoz et al. (2020), I test the effect of a placebo treatment allocation to the left of the observed treat- 

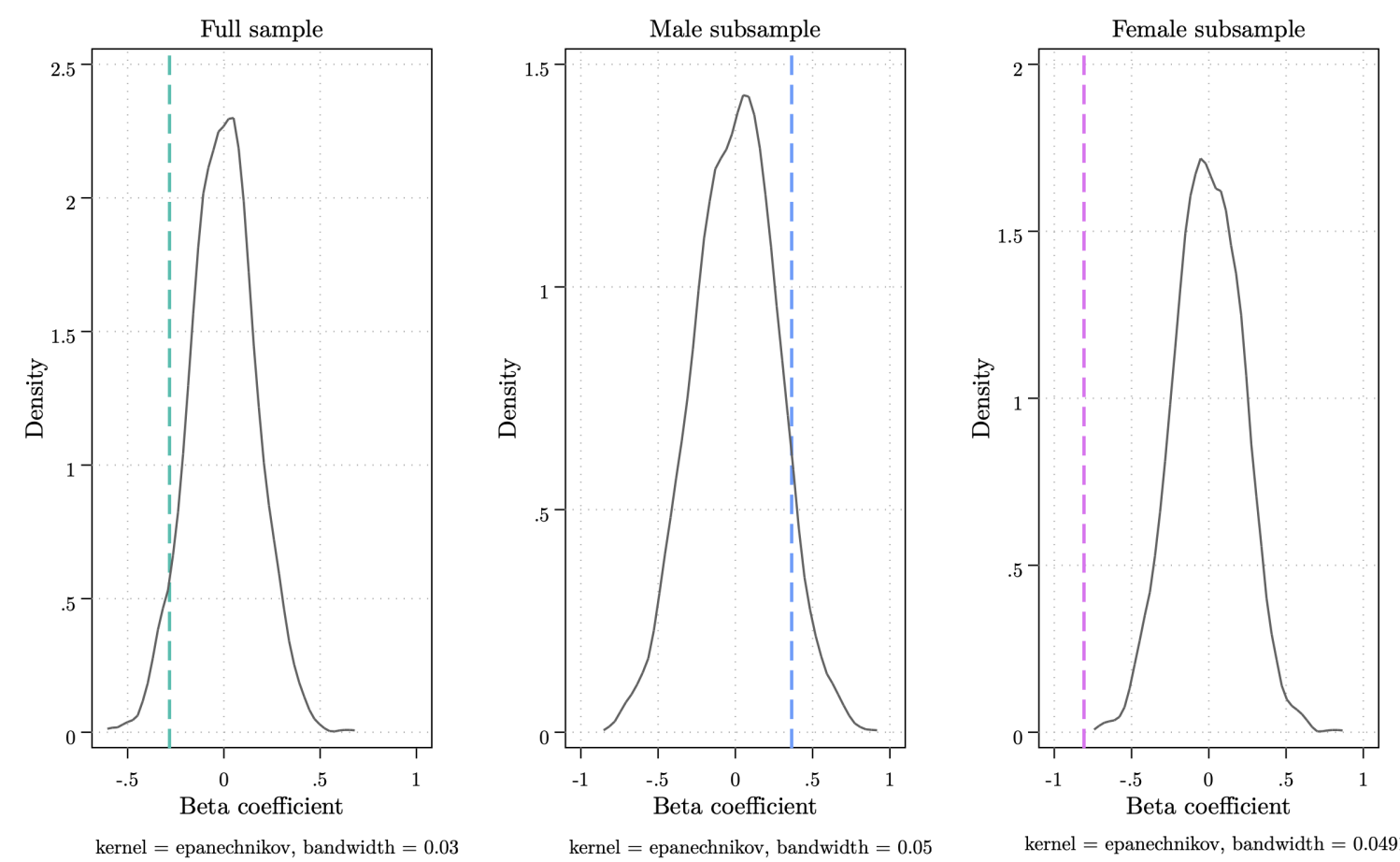

Based on x1000 random permutations per model

Figure 5: Permutation test

ment date taking the median interview date of the control group sample as placebo cut-off. This test shows that there are no pre-existing time trends that may be driving our results (Figure A2.) Second, I visualise and model a regression discontinuity design (Table A8 \& Figure A8). As in the case of the other robustness tests, there is no evidence of a pre-treatment trend but evidence of a substantive negative effect immediately after the treatment threshold.

In addition to these sensitivity analyses, I also explore for the effect of potential moderators that might condition the effect of the ruling on homonegative attitudes. Theoretically, one might expect the effect to be conditioned by ideological preferences with those on the right (already more prone to hold intolerant views towards homosexuality) most likely to be influenced by treatment. Testing for this, however, by including a multiplicative interaction term between treatment and left-right (0-10) preferences shows that this is not the case. As shown in Figure 6 those, both men and women, furthest on the right do not appear be to be influenced by the ruling. Although, this 

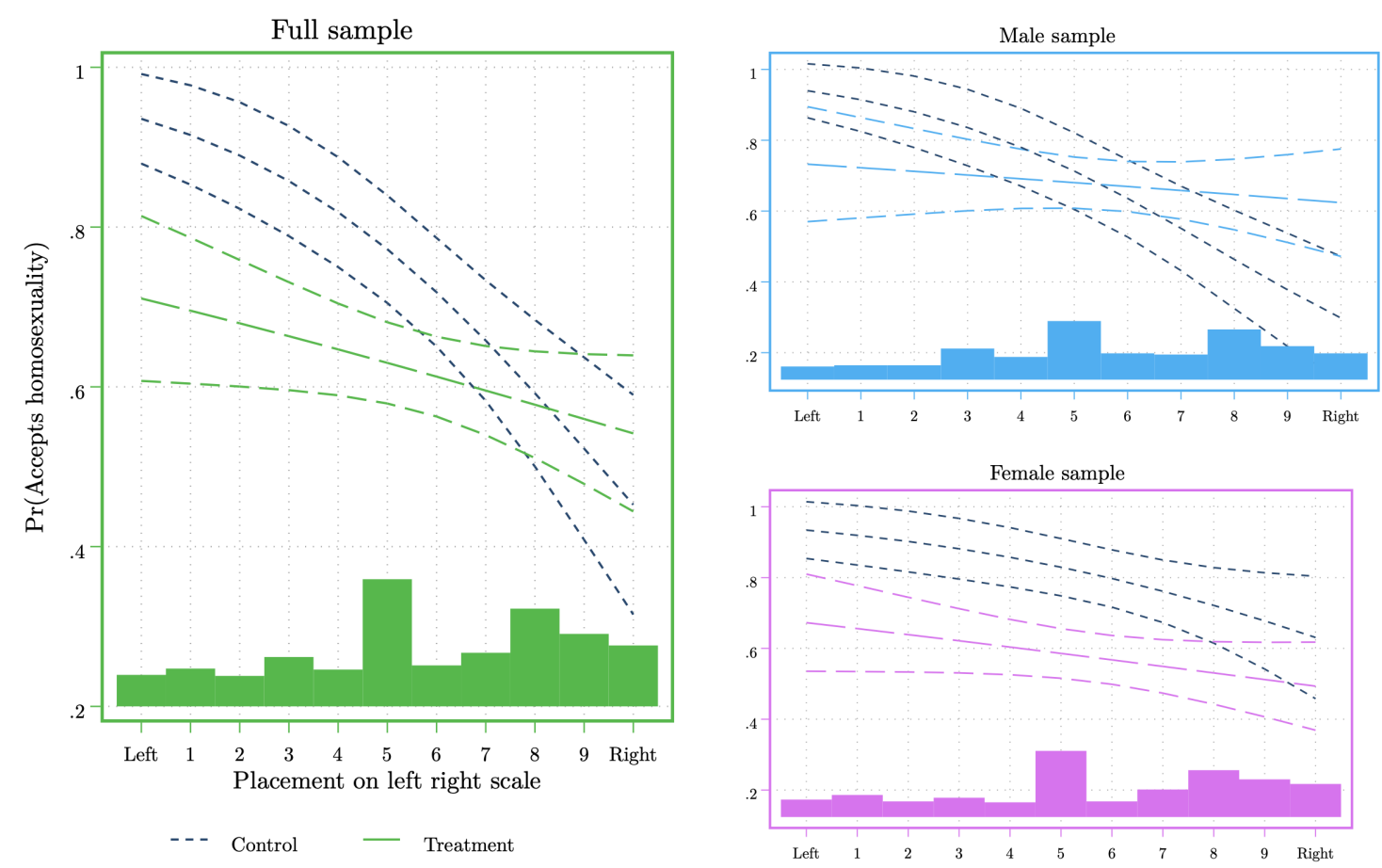

$95 \%$ confidence intervals

Figure 6: ITT effect conditioned by ideology

is likely the result of a floor effect since support for homosexuality is so low amongst those with far-right values that there is little scope for treatment to reduce it further. Of note is that there is a sizeable reduction in support for homosexuality amongst those who identify in the political centre (where a plurality of respondents spatially place themselves) as well as those on the left. This conditional effect, however, should be interpreted with caution. Given the low number of observations, the non-identifiable effect amongst far-right citizens may also be the result of limited statistical power.

Other moderators of theoretical interest such as education and engagement in politics (past participation) are also considered. In the case of education (Figure A6, the results show that the effect of treatment was only significantly distinct from zero amongst those without a university-level education ( $74 \%$ of the sample $-72 \%$ of men $\& 76 \%$ of women). The effect also holds across voters whilst it is insignificant amongst nonvoters (Figure A7). It should be noted, however, that only $11 \%$ of respondents identify as non-voters. 


\section{Discussion}

The results of the quasi-experimental test presented in the case of Israel shows that the US' legalisation of SSM via the SCOTUS ruling in Obergefell $v$. Hodges exhibited a significant negative effect on attitudes towards homosexuality. Israel is a useful and illustrative example of a country with limited progression on LGBT+ rights as well as a religiously-entrenched understanding of marriage (Gross, 2015).

Popular (international) punditry of LGBT+ politics in Israel has often penned Israel as somewhat of a vanguard leader of progressive politics within the Middle East. A critical reading of this image, however, portrays a different reality on the ground, and the Israeli state has been criticised for relying on tolerance of sexual minorities as a "pink-washing" (Gross, 2015; Puar, 2013) public relations tool in order to portray a homonationalist and liberal image of itself in comparison to its immediate geographic (and Arab) neighbours. Netanyahu's "pro-LGBT+" propaganda communicated to the outside world is often accompanied by complete silence on the same at home (Gross, 2015) or worse by outspoken homophobic remarks by some of the government's aggressively homophobic ministers ${ }^{8}$. Where LGBT+ advances have been made in Israel, these have frequently been the result of judicial action rather than political leadership or changes in the tide of public opinion (Harel, 1999).

At present, and at the time of the quasi-experiment events, SSM is not facilitated in Israel as marriages can only be officiated by the church. Beyond the institutional provision of LGBT+ rights, Gross (2015, p. 86) argues that "violent homophobia exists in Israel". This argument is echoed by Pizmony-Levy et al. (2019) who, relying on data from LGBT+ students in Israel, shows that the reality for LGBT+ individuals on the ground is still one in which homophobic and transphobic behaviour is commonplace.

\footnotetext{
${ }^{8}$ Education Secretary, Shai Piron, stated in 2014 that "the duty of the state to to tell same-sex couples that their family is not a family". In 2019, the latest Education Secretary, Rafi Peretz, claimed to have personally carried out conversion therapy young boys during his time as a chief Rabbi. In 2017, the Netenyahu-led government rejected proposals to permit the adoption of children by gay and lesbian couples claiming doing so would create difficulties for children.
} 
Whilst Pride parades have taken place in Tel Aviv for a number of years these too have often been accompanied by anti-LGBT protest movements (Pizmony-Levy et al., 2019) as well as murders in 2009 and $2015^{9}$.

The anticipatory backlash argument posits that actors in states that hold less progressive positions on LGBT+ rights and harbour negative views towards homosexuality will react negatively to progresses made by other states that advance LGBT+ rights (Mos, 2020; Weiss, 2013) particularly when the image of the historical identity of the state is closely tied to religion (Ayoub, 2014). The case of Israel complies with these scope conditions set out by the theory yet we might expect similar effects in other countries that meet these conditions. Moreover, whist the empirical test presented here relies on respondents' overall attitudes towards homosexuality, there is a theoretical basis for similar results to be observed over policy-specific attitudes such as adoption rights (Dotti Sani et al., 2020) or prohibitions on conversion therapy (Flores et al., 2020).

\section{Conclusions}

The introduction of same-sex marriage in the US is something that advocates of LGBT+ rights have celebrated as a significant turning point in the slow yet steady advancement towards the expansion of equal treatment of sexual minorities before the law. Pundits heralded the concrete case of the US - given the country's role as a leader on the world stage and exporter of international norms - because the legitimising effect of SSM there could serve as a signal to other states regarding the establishment of a new and inclusive norm. The results, however, show that the reverse is true. The contributions made here suggest that beyond the direct effects enjoyed by the state that enacts SSM, the progressive advances in LGBT+ rights that advance the welfare of LGBT+

\footnotetext{
9"Jerusalem Gay Pride: Israel teenage stabbing victim dies" August 2nd 2015, BBC News, https: //www.bbc.com/news/world-middle-east-33752111.

"Israeli gays' safe haven turns deadly" August 2nd 2009, Reuters, https://cn.reuters.com/article/ uk-israel-shooting-idUKTRE5710NX20090803
} 
individuals at home can have unintended and negative consequences abroad.

This letter provides the first effort to causally identify the potential for advances in LGBT+ rights to trigger a backlash beyond the confines of the domestic state. These findings speak directly to the literature concerned with domestic reactions to external (international) norms that are perceived as threatening (Ayoub, 2014) and anticipatory backlash (Mos, 2020; Weiss, 2013). The causal evidence presented here is, of course, limited by the single case for which we have empirical data. Whilst the evidence from this quasi-experiment is restricted to Israel, its empirical findings are largely in line with the observational and qualitative evidence presented in case studies in South East Asia (Weiss, 2013; Wijaya, 2020), Africa (Nuñez-Mietz et al., 2017), and Europe (Mos, 2020).

The negative and backlash-inducing effect of external advances in LGBT+ rights are observed in countries that have not yet themselves achieved the policies they are responding to. In other words, anticipatory backlash to the US' legalisation of SSM in Israel, as in the case of the evidence presented elsewhere in the literature, takes place in countries that hold a more inimical record on LGBT+ rights. This is an important constraint on the scope conditions: the backlash effect is unlikely to be observed in states that already provide SSM or other legal recognition of same-sex couples as these states that already adopted a norm that legitimises homosexuality. 


\section{References}

Abendschoen, S., \& Steinmetz, S. (2014). The Gender Gap in Voting Revisited: Women's Party Preferences in a European Context. Social Politics, 21(2), 315-344.

Abou-Chadi, T., \& Finnigan, R. (2019). Rights for Same-Sex Couples and Public Attitudes Toward Gays and Lesbians in Europe. Comparative Political Studies, 52(6), 868-895.

Ayoub, P. M. (2014). With Arms Wide Shut: Threat Perception, Norm Reception, and Mobilized Resistance to LGBT Rights. Journal of Human Rights, 13(3), 337-362.

Barisione, M. (2014). Debunking the myth of a "Traditional" gender gap in the electoral support for Silvio Berlusconi in Italy (1994-2013). Electoral Studies, 36, 117-128.

Bishin, B. G., Hayes, T. J., Incantalupo, M. B., \& Smith, C. A. (2016). Opinion Backlash and Public Attitudes: Are Political Advances in Gay Rights Counterproductive? American Journal of Political Science, 60(3), 625-648.

Campbell, R., \& Childs, S. (2015). 'To the left, to the right': Representing conservative women's interests. Party Politics, 21(4), 626-637.

Currier, A., \& Cruz, J. M. (2020). The politics of pre-emption: mobilisation against LGBT rights in Liberia. Social Movement Studies, 19(1), 82-96.

Delis, A., Matakos, K., \& Xefteris, D. (2020). Electoral Spillovers in an Intertwined World: Brexit Effects on the 2016 Spanish Vote. British Journal of Political Science, $50,1169-1174$.

Donovan, T., \& Tolbert, C. (2013). Do Popular Votes on Rights Create Animosity Toward Minorities? Political Research Quarterly, 66(4), 910-922.

Dotti Sani, G. M., \& Quaranta, M. (2020). Let Them Be, Not Adopt: General Attitudes Towards Gays and Lesbians and Specific Attitudes Towards Adoption by SameSex Couples in 22 European Countries. Social Indicators Research, 150(1), 351373.

Emmenneger Patrick, P., Manow. (2014). Religion and the Gender Vote Gap: Women's Changed Political Preferences from the 1970s to 2010. Politics E Society, 42(2), $166-193$. 
Flores, A. R., \& Barclay, S. (2016). Backlash, Consensus, Legitimacy, or Polarization: The Effect of Same-Sex Marriage Policy on Mass Attitudes. Political Research Quarterly, 69(1), 43-56.

Flores, A. R., Mallory, C., \& Conron, K. J. (2020). Public attitudes about emergent issues in LGBTQ rights: Conversion therapy and religious refusals. Research and Politics, 7(4), 1-9.

Giani, M. (2020). Fear without Prejudice in the Shadow of Jihadist Threat. Comparative Political Studies, Online First.

Giani, M., \& Méon, P.-G. (2019). Global Racist Contagion Following Donald Trump's Election. British Journal of Political Science, Online First.

Giger, N. (2009). Towards a modern gender gap in Europe? A comparative analysis of voting behavior in 12 countries. Social Science Journal, 46, 474-492.

Gross, A. (2015). The Politics of LGBT Rights in Israel and Beyond: Nationality, Normativity, and Queer Politics. Columbia Human Rights Law Review, 46(2), 81-152.

Harel, A. (1999). The rise and fall of the Israeli gay legal revolution. Columbia Human Rights Law Review, 31, 443-471.

Hooghe, M., \& Meeusen, C. (2013). Is same-sex marriage legislation related to attitudes toward homosexuality?: Trends in tolerance of homosexuality in european countries between 2002 and 2010. Sexuality Research and Social Policy, 10(4), $258-268$.

Inglehart, R., \& Norries, P. (2003). Rising Tide: Gender Equality and Cultural Change Around the World. Cambridge University Press.

Klarman, M. J. (2012). From the Closet to the Altar: Courts, Backlash, and the Struggle for Same-Sex Marriage. Oxford University Press.

Kollman, K. (2013). The same-sex unions revolution in Western democracies: International norms and domestic policy change. Manchester University Press.

Kreitzer, R. J., Hamilton, A. J., \& Tolbert, C. J. (2014). Does Policy Adoption Change Opinions on Minority Rights? The Effects of Legalizing Same-Sex Marriage. Political Research Quarterly, 67(4), 795-808. 
Mos, M. (2020). The anticipatory politics of homophobia: explaining constitutional bans on same-sex marriage in post-communist Europe. East European Politics, 36(3), 395-416.

Muñoz, J., Falcó-Gimeno, A., \& Hernández, E. (2020). Unexpected Event during Survey Design: Promise and Pitfalls for Causal Inference. Political Analysis, 28(2), 186-206.

Nuñez-Mietz, F. G., \& Iommi, L. G. (2017). Can transnational norm advocacy undermine internalization? Explaining immunization against LGBT rights in Uganda. International Studies Quarterly, 61(1), 196-209.

O'Dwyer, C. (2012). Does the EU help or hinder gay-rights movements in post-communist europe? The case of Poland. East European Politics, 28(4), 332-352.

Paternotte, D., \& Kollman, K. (2013). Regulating intimate relationships in the European polity: same-sex unions and policy convergence. Social Politics, 4, 510-533.

Pizmony-Levy, O., Rogel, A., \& Shilo, G. (2019). Pride and the True Colors of the Holy Land: School Climate for Lesbian, Gay, Bisexual, and Transgender Students in Israel. International Journal of Educational Development, 70.

Puar, J. (2013). Rethinking homonationalism. International Journal of Middle East Studies, 45(2), 336-339.

Shapiro, R. Y., \& Mahajan, H. (1986). Gender Differences in Policy Preferences: A Summary of Trends from the 1960s to the 1980s. Public Opinion Quarterly, 50(1), 4261.

Soss, J., \& Schram, S. F. (2007). A public transformed? Welfare reform as policy feedback. American Political Science Review, 101(1), 111-127.

Takács, J., \& Szalma, I. (2011). Homophobia and same-sex partnership legislation in Europe. Equality, Diversity and Inclusion: An International Journal, 30(5), 356-378.

Weiss, M. L. (2013). Prejudice before pride: Rise of an anticipatory countermovement. In M. L. Weiss \& M. J. Bosia (Eds.), Global homophobia: States, movements, and the politics of oppression (pp. 150-173). University of Illinois Press. 
Wijaya, H. Y. (2020). Conservative Islamic Forces, Global LGBT Rights, and Anticipatory Homophobia in Indonesia. In M. Derks \& M. van den Berg (Eds.), Public discourses about homosexuality and religion in europe and beyond (pp. 325-348). Springer. 


\section{Appendix}

\section{Additional models}

Table A1: Placebo models

\begin{tabular}{lcccccc}
\hline X & $\begin{array}{c}(1) \\
\text { Redistribution } \\
\text { Women }\end{array}$ & $\begin{array}{c}\text { Redistribution } \\
\text { Men }\end{array}$ & $\begin{array}{c}(3) \\
\text { Immigration } \\
\text { Women }\end{array}$ & $\begin{array}{c}(4) \\
\text { Immigration } \\
\text { Men }\end{array}$ & $\begin{array}{c}(5) \\
\text { Economy } \\
\text { Women }\end{array}$ & $\begin{array}{c}(6) \\
\text { Economy } \\
\text { Men }\end{array}$ \\
\hline \multirow{3}{*}{ Treatment } & & & & & & \\
& 0.09 & -0.24 & -0.04 & -0.43 & -0.06 & 0.24 \\
Age & $(0.32)$ & $(0.35)$ & $(0.28)$ & $(0.32)$ & $(0.32)$ & $(0.33)$ \\
& 0.01 & $0.02^{*}$ & 0.01 & $0.02^{* *}$ & 0.01 & $0.02^{* *}$ \\
Left-right position & $(0.01)$ & $(0.01)$ & $(0.01)$ & $(0.01)$ & $(0.01)$ & $(0.01)$ \\
& -0.03 & -0.01 & 0.05 & -0.06 & 0.05 & $0.10^{*}$ \\
Income & $(0.05)$ & $(0.06)$ & $(0.05)$ & $(0.05)$ & $(0.05)$ & $(0.06)$ \\
& 0.08 & -0.09 & $0.10^{*}$ & $0.21^{* * *}$ & -0.05 & $0.14^{* *}$ \\
Education & $(0.07)$ & $(0.07)$ & $(0.06)$ & $(0.07)$ & $(0.07)$ & $(0.07)$ \\
& 0.03 & 0.04 & 0.03 & 0.02 & $0.09^{* *}$ & $0.13^{* * *}$ \\
Constant & $(0.04)$ & $(0.05)$ & $(0.04)$ & $(0.05)$ & $(0.04)$ & $(0.05)$ \\
& $-1.69^{*}$ & -1.00 & $-2.18^{* *}$ & $-1.70^{*}$ & $-2.59^{* * *}$ & $-4.55^{* * *}$ \\
& $(0.90)$ & $(0.98)$ & $(0.86)$ & $(0.94)$ & $(0.88)$ & $(0.94)$ \\
Observations & & & & & & \\
\hline
\end{tabular}

Robust standard errors in parentheses

${ }^{* * *} \mathrm{p}<0.01,{ }^{* *} \mathrm{p}<0.05,{ }^{*} \mathrm{p}<0.1$ 
Comparison of weighted v. unweighted models

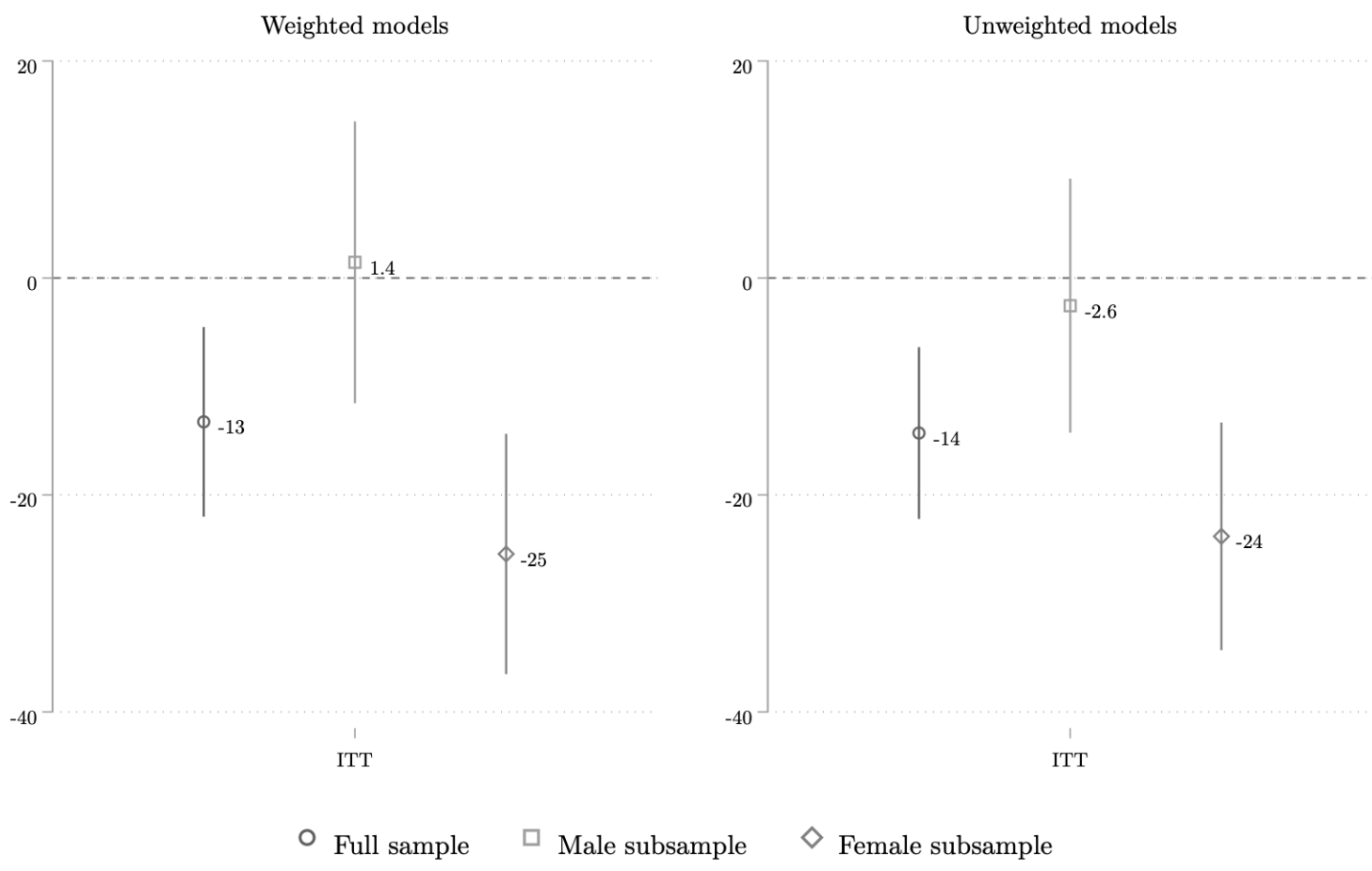

Figure A1: Robustness test: Survey weights

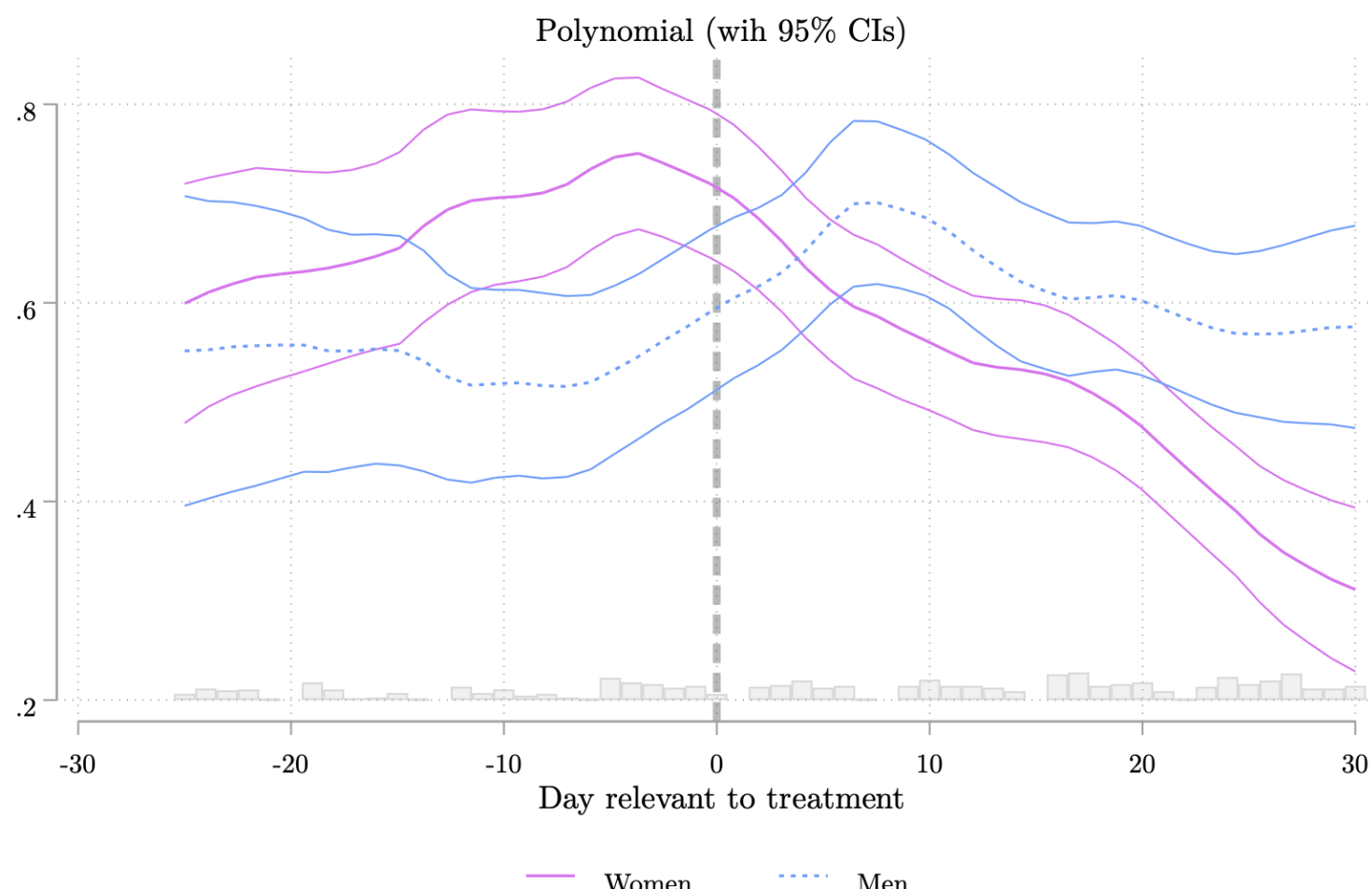

Figure A2: Polynomial 


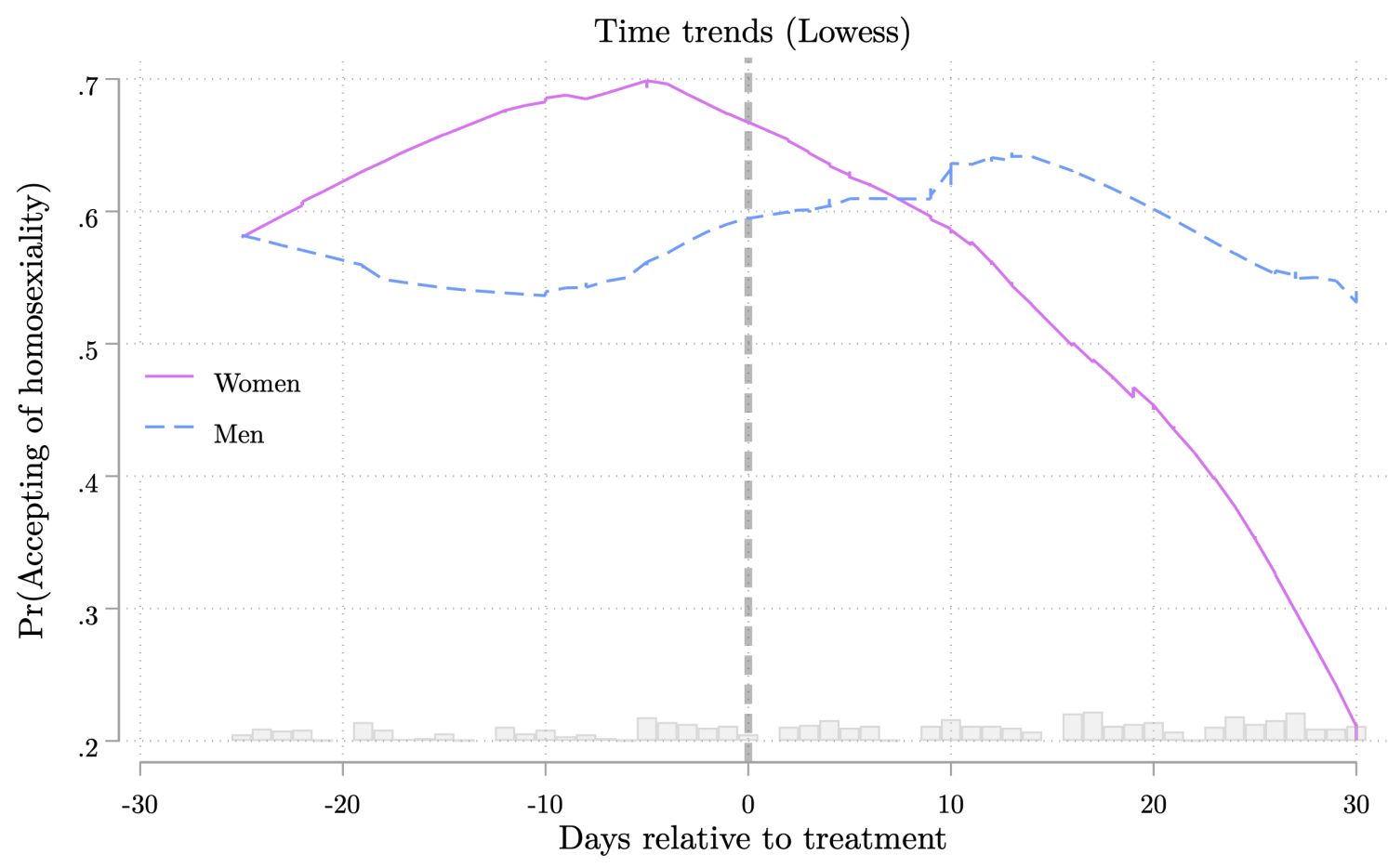

Lowess model

Figure A3: Trends 
Table A2: Model testing pre-treatment trends using median date placebo

\begin{tabular}{|c|c|c|c|}
\hline Median(pre-treatment) date & $\begin{array}{c}(1) \\
\text { Full sample }\end{array}$ & $\begin{array}{c}(2) \\
\text { Women }\end{array}$ & $\begin{array}{c}(3) \\
\text { Men }\end{array}$ \\
\hline Placebo & $\begin{array}{l}-0.29 \\
(0.28)\end{array}$ & $\begin{array}{c}0.29 \\
(0.39)\end{array}$ & $\begin{array}{l}-0.70^{*} \\
(0.42)\end{array}$ \\
\hline Constant & $\begin{array}{c}0.67^{* * *} \\
(0.23)\end{array}$ & $\begin{array}{c}0.83^{* * *} \\
(0.29)\end{array}$ & $\begin{array}{c}0.46 \\
(0.36)\end{array}$ \\
\hline Observations & 290 & 157 & 133 \\
\hline
\end{tabular}

Table A3: Models controlling for self-reported religiosity

\begin{tabular}{|c|c|c|c|}
\hline$x$ & $\begin{array}{c}\text { (1) } \\
\text { Full sample }\end{array}$ & $\begin{array}{l}(2) \\
\text { Men }\end{array}$ & $\begin{array}{c}(3) \\
\text { Women }\end{array}$ \\
\hline Treatment & $\begin{array}{c}-0.70^{* * *} \\
(0.24)\end{array}$ & $\begin{array}{l}-0.20 \\
(0.39)\end{array}$ & $\begin{array}{c}-1.15^{* * *} \\
(0.32)\end{array}$ \\
\hline Gender & $\begin{array}{c}0.27 \\
(0.24)\end{array}$ & & \\
\hline Agea & $\begin{array}{l}-0.01^{* *} \\
(0.01)\end{array}$ & $\begin{array}{l}-0.01 \\
(0.01)\end{array}$ & $\begin{array}{l}-0.02^{* *} \\
(0.01)\end{array}$ \\
\hline Income & $\begin{array}{c}0.20^{* * *} \\
(0.06)\end{array}$ & $\begin{array}{l}0.21^{* *} \\
(0.08)\end{array}$ & $\begin{array}{c}0.20^{* * *} \\
(0.07)\end{array}$ \\
\hline Education & $\begin{array}{l}0.07^{* *} \\
(0.03)\end{array}$ & $\begin{array}{l}0.12^{* *} \\
(0.05)\end{array}$ & $\begin{array}{c}0.05 \\
(0.04)\end{array}$ \\
\hline Left-right position & $\begin{array}{c}-0.10^{* *} \\
(0.04)\end{array}$ & $\begin{array}{l}-0.13^{*} \\
(0.07)\end{array}$ & $\begin{array}{l}-0.08 \\
(0.05)\end{array}$ \\
\hline Religiosity & $\begin{array}{c}-0.23^{* * *} \\
(0.04)\end{array}$ & $\begin{array}{c}-0.26^{* * *} \\
(0.06)\end{array}$ & $\begin{array}{c}-0.18^{* * *} \\
(0.05)\end{array}$ \\
\hline Constant & $\begin{array}{l}1.20^{*} \\
(0.66)\end{array}$ & $\begin{array}{c}0.33 \\
(1.10)\end{array}$ & $\begin{array}{l}1.79^{* *} \\
(0.81)\end{array}$ \\
\hline Observations & 517 & 214 & 303 \\
\hline
\end{tabular}


Table A4: Models controlling for religious observance

\begin{tabular}{|c|c|c|c|}
\hline$x$ & $\begin{array}{c}\text { (1) } \\
\text { Full sample }\end{array}$ & $\begin{array}{l}\text { (2) } \\
\text { Men }\end{array}$ & $\begin{array}{c}(3) \\
\text { Women }\end{array}$ \\
\hline Treatment & $\begin{array}{c}-0.70^{* * *} \\
(0.26)\end{array}$ & $\begin{array}{l}-0.12 \\
(0.39)\end{array}$ & $\begin{array}{c}-1.27^{* * *} \\
(0.36)\end{array}$ \\
\hline Gender & $\begin{array}{c}0.08 \\
(0.26)\end{array}$ & & \\
\hline Age & $\begin{array}{c}-0.02^{* *} \\
(0.01)\end{array}$ & $\begin{array}{l}-0.01 \\
(0.01)\end{array}$ & $\begin{array}{c}-0.02^{* *} \\
(0.01)\end{array}$ \\
\hline Income & $\begin{array}{c}0.18^{* * *} \\
(0.06)\end{array}$ & $\begin{array}{l}0.19^{* *} \\
(0.08)\end{array}$ & $\begin{array}{c}0.20^{* * *} \\
(0.07)\end{array}$ \\
\hline Education & $\begin{array}{l}0.09^{* *} \\
(0.03)\end{array}$ & $\begin{array}{l}0.12^{* *} \\
(0.05)\end{array}$ & $\begin{array}{c}0.06 \\
(0.04)\end{array}$ \\
\hline Left-right position & $\begin{array}{c}-0.12^{* * *} \\
(0.04)\end{array}$ & $\begin{array}{c}-0.15^{* *} \\
(0.07)\end{array}$ & $\begin{array}{c}-0.10^{*} \\
(0.06)\end{array}$ \\
\hline Prays (ref: never) & & & \\
\hline Everyday & $\begin{array}{c}-2.09^{* * * *} \\
(0.31)\end{array}$ & $\begin{array}{c}-1.67^{* * *} \\
(0.49)\end{array}$ & $\begin{array}{c}-2.23^{* * *} \\
(0.40)\end{array}$ \\
\hline$>1 /$ week & $\begin{array}{l}-0.97^{*} \\
(0.55)\end{array}$ & $\begin{array}{l}-1.52 \\
(1.15)\end{array}$ & $\begin{array}{l}-0.65 \\
(0.66)\end{array}$ \\
\hline 1/week & $\begin{array}{l}-0.43 \\
(0.53)\end{array}$ & $\begin{array}{l}-1.15 \\
(0.83)\end{array}$ & $\begin{array}{c}0.17 \\
(0.59)\end{array}$ \\
\hline $1 /$ month & $\begin{array}{c}-1.20^{* * *} \\
(0.60)\end{array}$ & $\begin{array}{c}0.28 \\
(1.09)\end{array}$ & $\begin{array}{c}-2.66^{* * * *} \\
(0.85)\end{array}$ \\
\hline Special days & $\begin{array}{l}-0.12 \\
(0.39)\end{array}$ & $\begin{array}{c}0.26 \\
(0.55)\end{array}$ & $\begin{array}{l}-0.40 \\
(0.65)\end{array}$ \\
\hline Less often & $\begin{array}{c}0.50 \\
(0.43)\end{array}$ & $\begin{array}{c}0.66 \\
(0.83)\end{array}$ & $\begin{array}{c}0.53 \\
(0.56)\end{array}$ \\
\hline Constant & $\begin{array}{c}1.05 \\
(0.73)\end{array}$ & $\begin{array}{c}0.04 \\
(1.10)\end{array}$ & $\begin{array}{l}1.87^{* * *} \\
(0.94)\end{array}$ \\
\hline Observations & 520 & 214 & 306 \\
\hline
\end{tabular}


Table A5: OLS Model (1 [Strongly Agree] - 5 [Strongly Disagree]

\begin{tabular}{|c|c|c|c|}
\hline$X$ & $\begin{array}{c}\text { (1) } \\
\text { Full sample }\end{array}$ & $\begin{array}{l}\text { (2) } \\
\text { Men }\end{array}$ & $\begin{array}{c}(3) \\
\text { Women }\end{array}$ \\
\hline Treatment & $\begin{array}{c}0.18 \\
(0.12)\end{array}$ & $\begin{array}{l}-0.26 \\
(0.18)\end{array}$ & $\begin{array}{c}0.58^{* * *} \\
(0.15)\end{array}$ \\
\hline Gender & $\begin{array}{l}-0.06 \\
(0.11)\end{array}$ & & \\
\hline Age & $\begin{array}{l}0.01^{* *} \\
(0.00)\end{array}$ & $\begin{array}{l}0.01^{* *} \\
(0.00)\end{array}$ & $\begin{array}{c}0.01 \\
(0.00)\end{array}$ \\
\hline Left-right position & $\begin{array}{l}0.09^{* * *} \\
(0.02)\end{array}$ & $\begin{array}{c}0.12^{* * *} \\
(0.03)\end{array}$ & $\begin{array}{l}0.06^{* *} \\
(0.03)\end{array}$ \\
\hline Income & $\begin{array}{c}-0.08^{* * *} \\
(0.03)\end{array}$ & $\begin{array}{l}-0.08^{*} \\
(0.04)\end{array}$ & $\begin{array}{c}-0.10^{* * *} \\
(0.03)\end{array}$ \\
\hline Education & $\begin{array}{c}-0.06^{* * *} \\
(0.02)\end{array}$ & $\begin{array}{c}-0.08^{* * *} \\
(0.02)\end{array}$ & $\begin{array}{l}-0.04^{* *} \\
(0.02)\end{array}$ \\
\hline Constant & $\begin{array}{c}2.47^{* * *} \\
(0.32)\end{array}$ & $\begin{array}{c}2.77^{* * *} \\
(0.50)\end{array}$ & $\begin{array}{c}2.24^{* * *} \\
(0.40)\end{array}$ \\
\hline Observations & 647 & 279 & 368 \\
\hline R-squared & 0.10 & 0.16 & 0.10 \\
\hline
\end{tabular}


Table A6: Ordinal logistic regression model (1 [Strongly Agree] - 5 [Strongly Disagree]

\begin{tabular}{|c|c|c|c|}
\hline$X$ & $\begin{array}{c}\text { (1) } \\
\text { Full sample }\end{array}$ & $\begin{array}{l}\text { (2) } \\
\text { Men }\end{array}$ & $\begin{array}{c}(3) \\
\text { Women }\end{array}$ \\
\hline Treatment & $\begin{array}{l}0.31^{*} \\
(0.17)\end{array}$ & $\begin{array}{l}-0.32 \\
(0.25)\end{array}$ & $\begin{array}{c}0.89^{* * *} \\
(0.23)\end{array}$ \\
\hline Gender & $\begin{array}{l}-0.09 \\
(0.16)\end{array}$ & & \\
\hline Age & $\begin{array}{c}0.01^{* * *} \\
(0.00)\end{array}$ & $\begin{array}{l}0.01^{* *} \\
(0.01)\end{array}$ & $\begin{array}{l}0.01^{* *} \\
(0.01)\end{array}$ \\
\hline Left-right position & $\begin{array}{c}0.13^{* * *} \\
(0.03)\end{array}$ & $\begin{array}{c}0.18^{* * *} \\
(0.05)\end{array}$ & $\begin{array}{l}0.08^{* *} \\
(0.04)\end{array}$ \\
\hline Income & $\begin{array}{c}-0.12^{* * *} \\
(0.04)\end{array}$ & $\begin{array}{l}-0.12^{*} \\
(0.06)\end{array}$ & $\begin{array}{c}-0.13^{* *} \\
(0.05)\end{array}$ \\
\hline Education & $\begin{array}{c}-0.08^{* * * *} \\
(0.02)\end{array}$ & $\begin{array}{c}-0.11^{* * *} \\
(0.04)\end{array}$ & $\begin{array}{c}-0.05^{* *} \\
(0.03)\end{array}$ \\
\hline /cut1 & $\begin{array}{l}-0.36 \\
(0.47)\end{array}$ & $\begin{array}{l}-0.93 \\
(0.77)\end{array}$ & $\begin{array}{c}0.18 \\
(0.58)\end{array}$ \\
\hline /cut2 & $\begin{array}{c}0.46 \\
(0.47)\end{array}$ & $\begin{array}{l}-0.03 \\
(0.77)\end{array}$ & $\begin{array}{l}0.98^{*} \\
(0.58)\end{array}$ \\
\hline / cut3 & $\begin{array}{l}1.42^{* * *} \\
(0.47)\end{array}$ & $\begin{array}{c}1.01 \\
(0.77)\end{array}$ & $\begin{array}{c}1.90^{* * *} \\
(0.59)\end{array}$ \\
\hline / cut4 & $\begin{array}{c}2.00^{* * *} \\
(0.48)\end{array}$ & $\begin{array}{l}1.64^{* *} \\
(0.78)\end{array}$ & $\begin{array}{c}2.46^{* * *} \\
(0.59)\end{array}$ \\
\hline Observations & 647 & 279 & 368 \\
\hline
\end{tabular}


Table A7: Model without ESS design weights

\begin{tabular}{|c|c|c|c|}
\hline$X$ & $\begin{array}{c}\text { (1) } \\
\text { Full sample }\end{array}$ & $\begin{array}{l}(2) \\
\text { Men }\end{array}$ & $\begin{array}{c}(3) \\
\text { Women }\end{array}$ \\
\hline Treatment & $\begin{array}{l}-0.44^{* *} \\
(0.19)\end{array}$ & $\begin{array}{c}0.19 \\
(0.28)\end{array}$ & $\begin{array}{c}-0.95^{* * *} \\
(0.26)\end{array}$ \\
\hline Gender & $\begin{array}{c}0.07 \\
(0.18)\end{array}$ & & \\
\hline Age & $\begin{array}{l}-0.01 \\
(0.00)\end{array}$ & $\begin{array}{l}-0.01 \\
(0.01)\end{array}$ & $\begin{array}{l}-0.00 \\
(0.01)\end{array}$ \\
\hline Left-right position & $\begin{array}{c}-0.10^{* * *} \\
(0.03)\end{array}$ & $\begin{array}{c}-0.13^{* *} \\
(0.05)\end{array}$ & $\begin{array}{c}-0.08^{* *} \\
(0.04)\end{array}$ \\
\hline Income & $\begin{array}{c}0.18^{* * *} \\
(0.04)\end{array}$ & $\begin{array}{c}0.19^{* * *} \\
(0.07)\end{array}$ & $\begin{array}{c}0.20^{* * *} \\
(0.06)\end{array}$ \\
\hline Education & $\begin{array}{c}0.12^{* * *} \\
(0.03)\end{array}$ & $\begin{array}{c}0.18^{* * *} \\
(0.05)\end{array}$ & $\begin{array}{l}0.08^{* *} \\
(0.03)\end{array}$ \\
\hline Constant & $\begin{array}{l}-0.77 \\
(0.53)\end{array}$ & $\begin{array}{c}-1.70^{* *} \\
(0.86)\end{array}$ & $\begin{array}{l}-0.25 \\
(0.66)\end{array}$ \\
\hline Observations & 647 & 279 & 368 \\
\hline
\end{tabular}



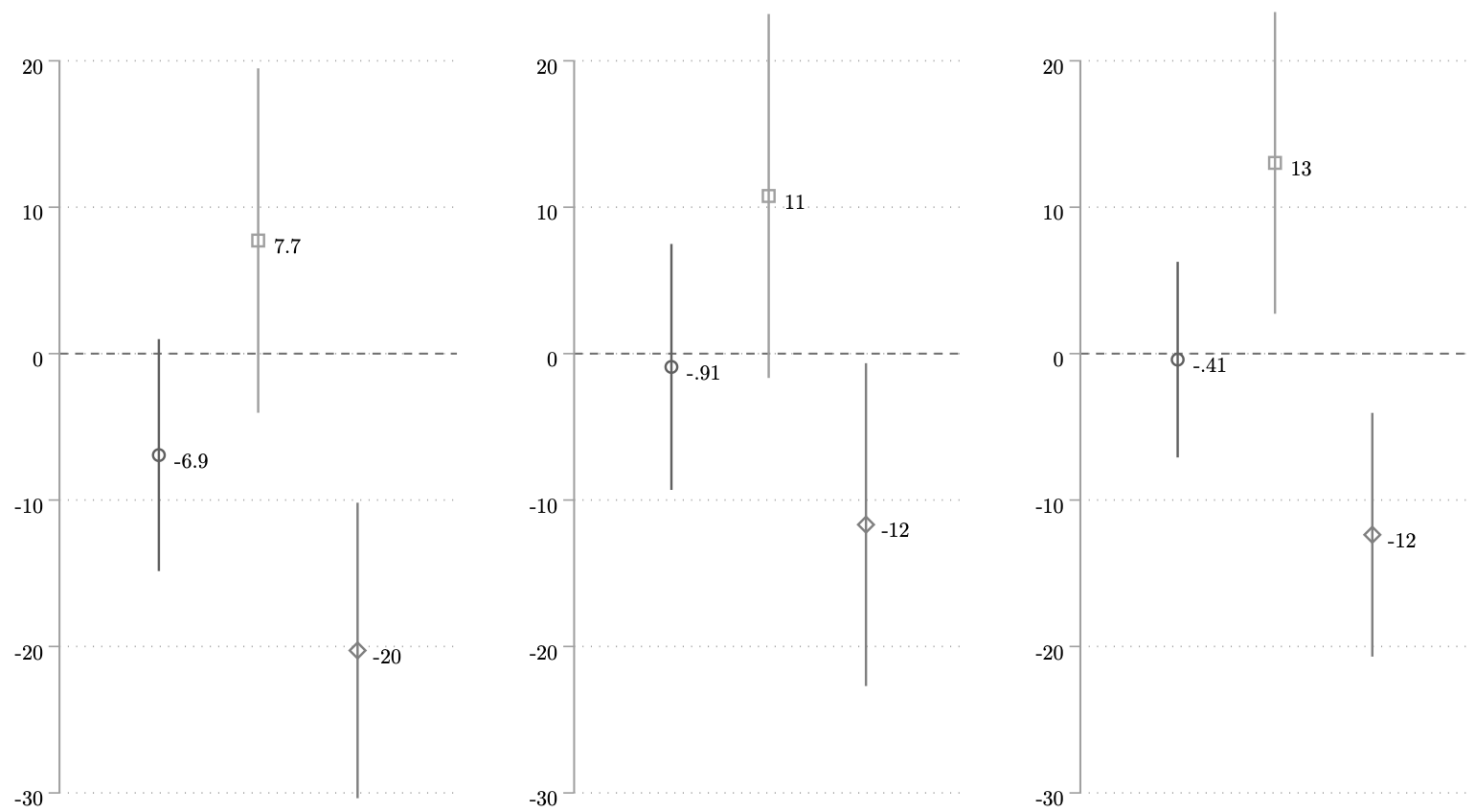

○ Full sample

$\square$ Male subsample $\diamond$ Female subsample

Figure A4: Alternative bandwidth cut-offs 
$\operatorname{Pr}$ (Missing outcome) by treatment assignment

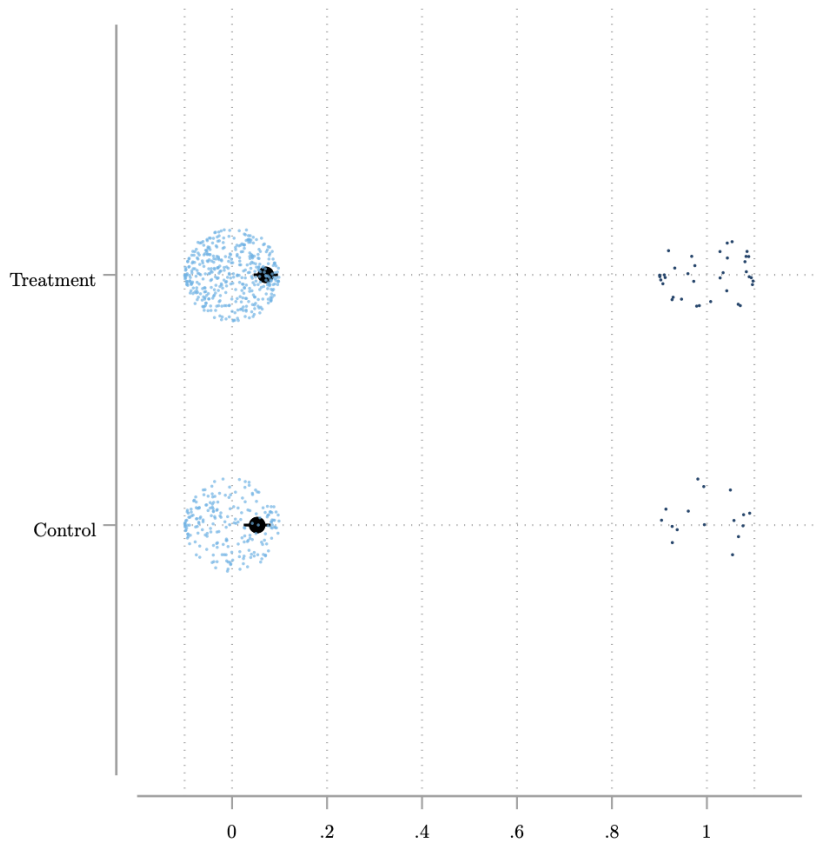

Figure A5: Attrition test 

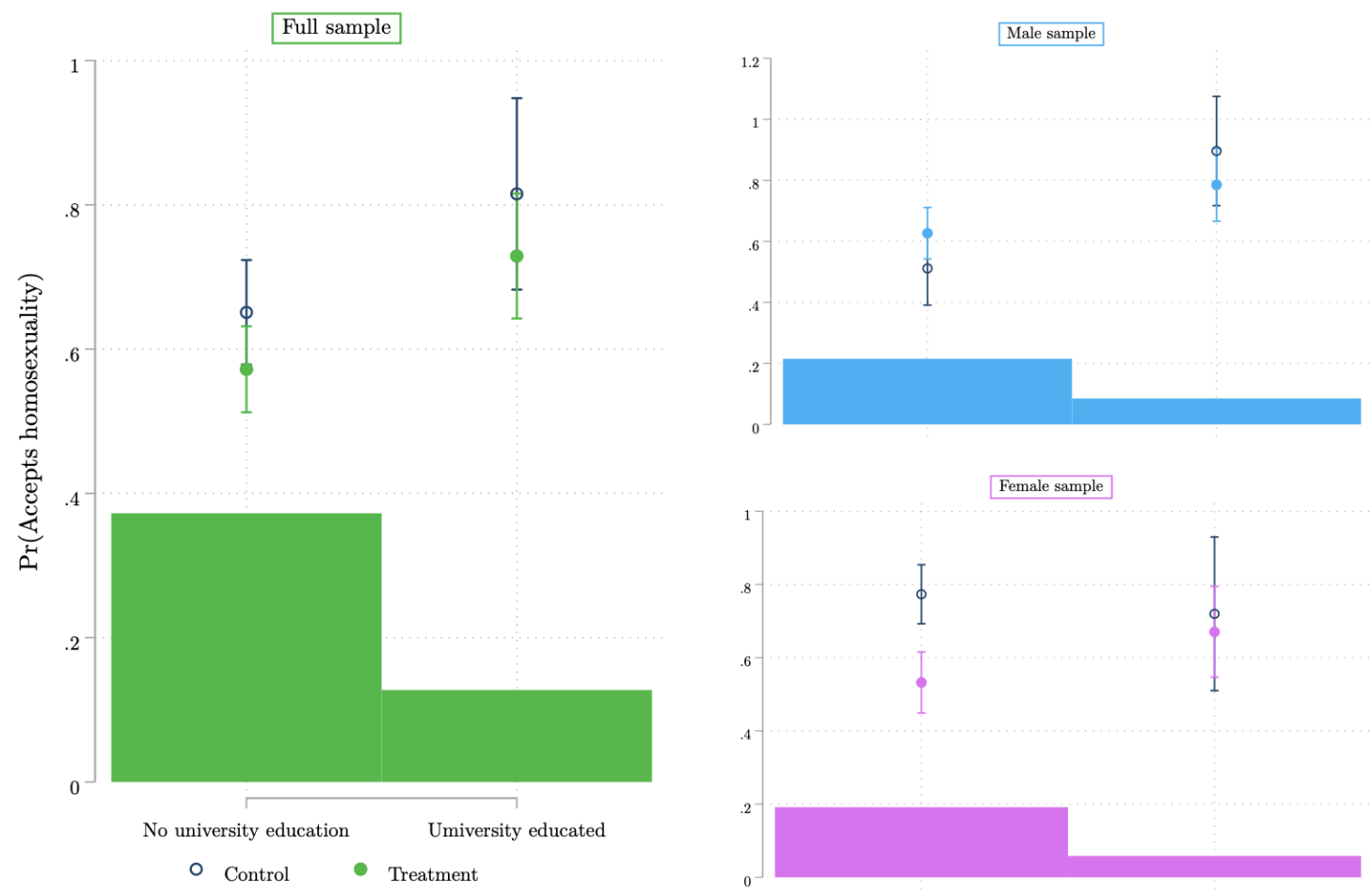

Figure A6: ITT effect conditioned by education levels

\section{Exploratory analysis of moderators}



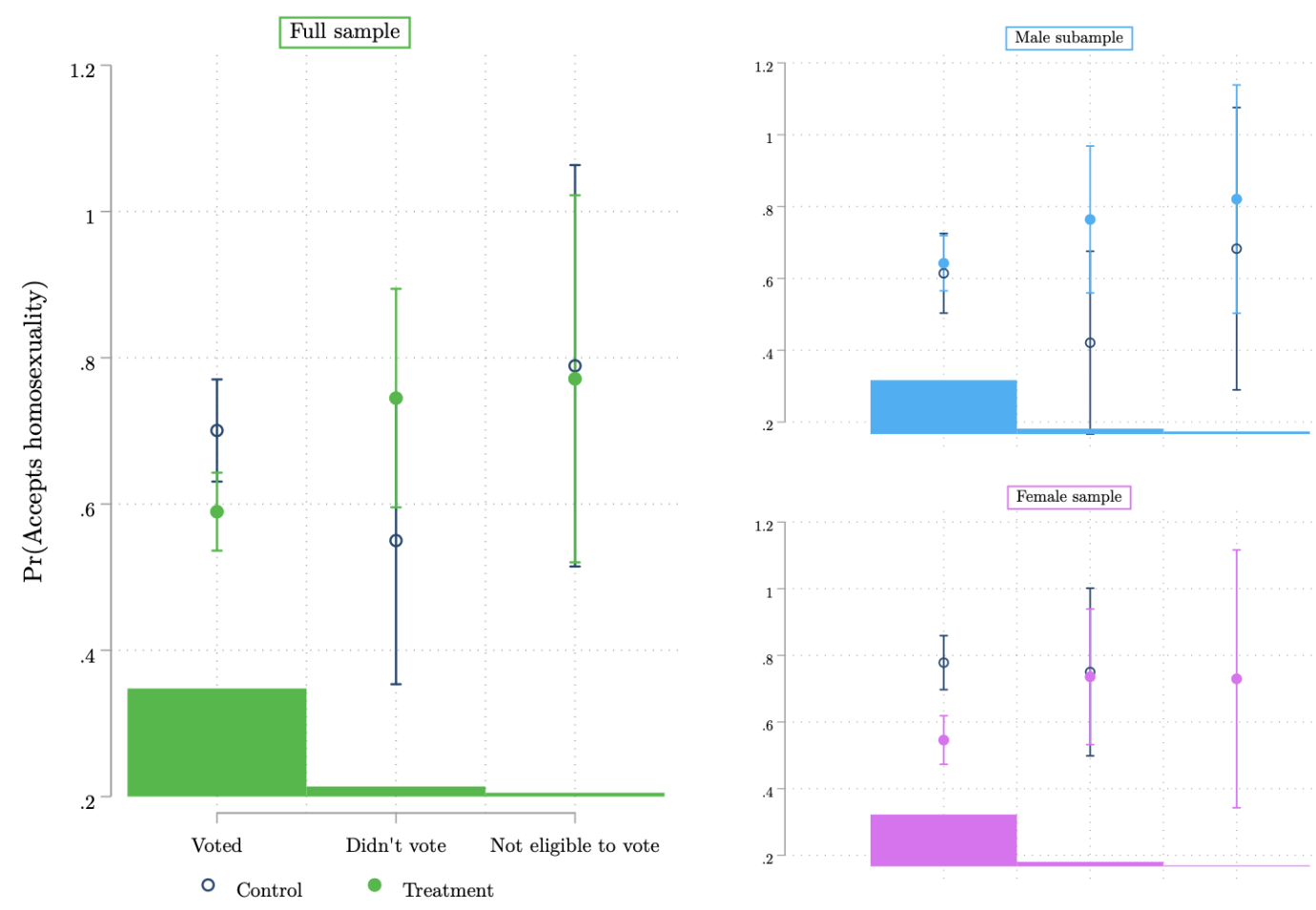

Figure A7: ITT effect conditioned by former participation level 


\section{RDD models}

Table A8: Estimation using Regression Discontinuity Design approach

\begin{tabular}{|c|c|c|c|c|c|c|}
\hline$x$ & $\begin{array}{c}(1) \\
\text { Full sample } \\
\text { No covariates }\end{array}$ & $\begin{array}{c}\text { (2) } \\
\text { Full sample } \\
\text { with covariates }\end{array}$ & $\begin{array}{c}\text { (3) } \\
\text { Men } \\
\text { No covariates }\end{array}$ & $\begin{array}{c}\text { (4) } \\
\text { Men } \\
\text { with covariates }\end{array}$ & $\begin{array}{c}(5) \\
\text { Women } \\
\text { No covariates }\end{array}$ & $\begin{array}{c}\text { (6) } \\
\text { Women } \\
\text { with covariates }\end{array}$ \\
\hline RD estimate & $\begin{array}{c}-0.09 \\
(0.20)\end{array}$ & $\begin{array}{c}0.07 \\
(0.14)\end{array}$ & $\begin{array}{c}-0.41 \\
(0.38)\end{array}$ & $\begin{array}{l}-0.39 \\
(0.26)\end{array}$ & $\begin{array}{l}0.41^{* *} \\
(0.16)\end{array}$ & $\begin{array}{c}0.39^{* * *} \\
(0.15)\end{array}$ \\
\hline Observations & 647 & 647 & 279 & 279 & 368 & 368 \\
\hline
\end{tabular}


Regression functional fit
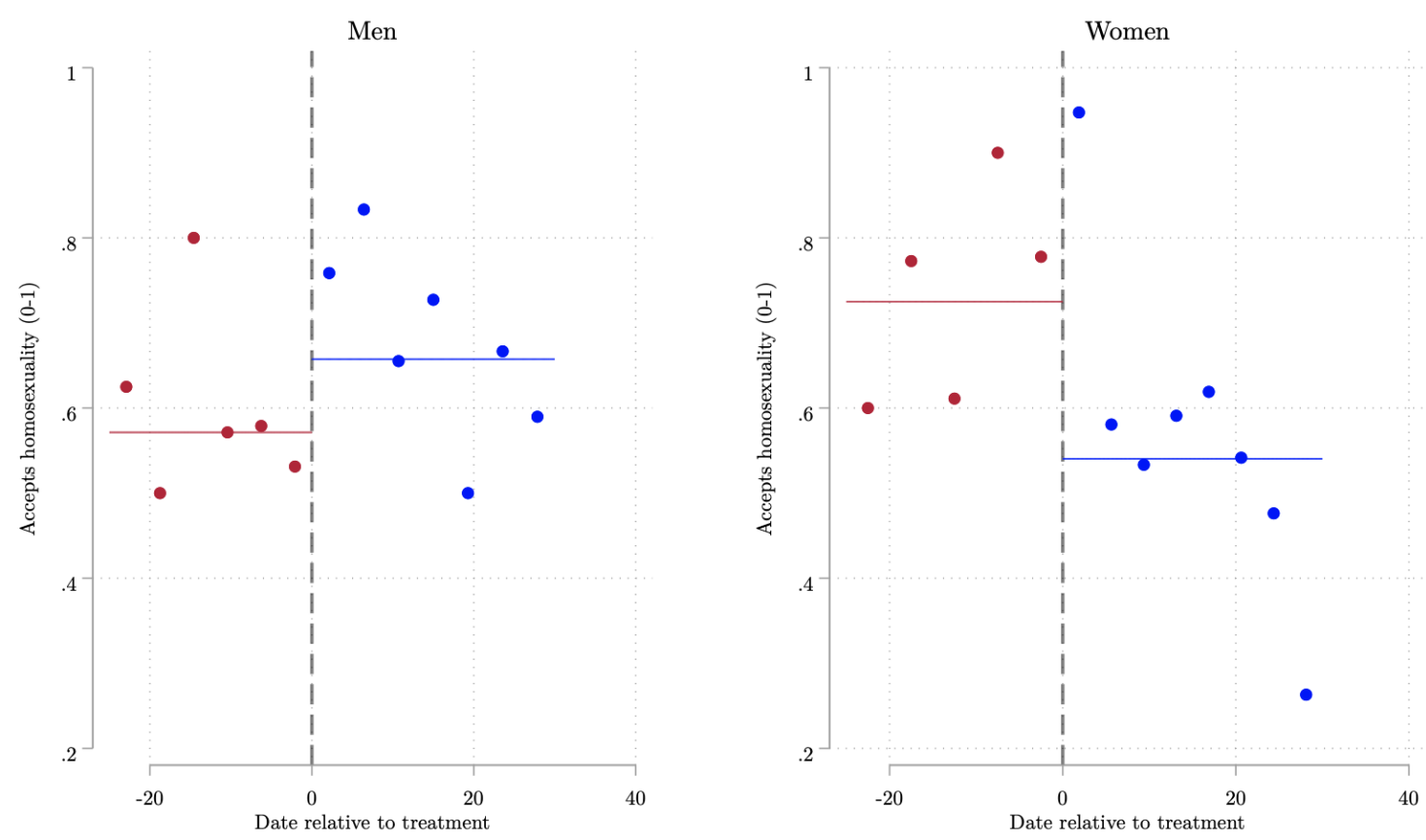

Based on IMSE-optimal equally spaced bins

Figure A8: RDD plot with binary outcome variable

Regression functional fit
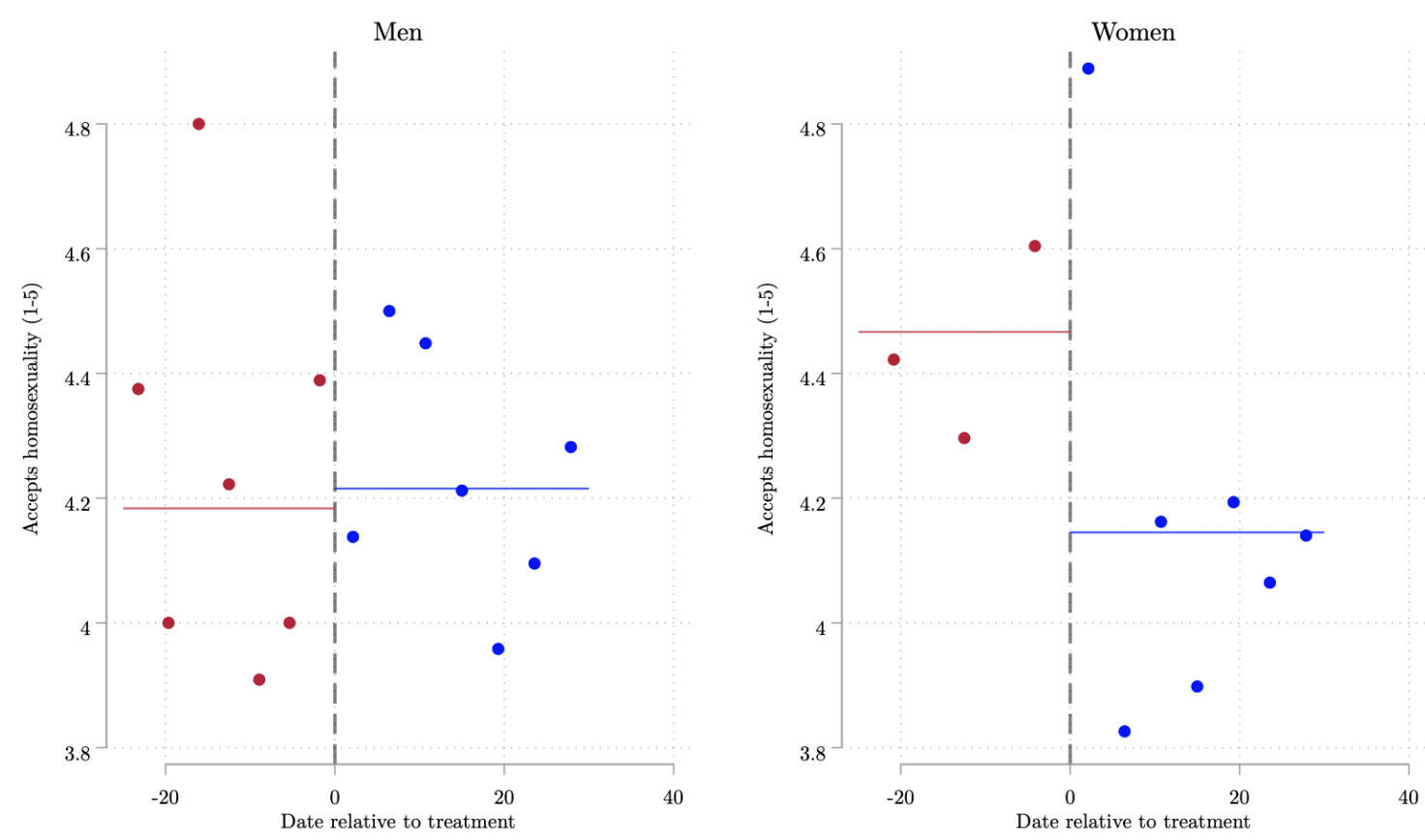

Based on IMSE-optimal equally spaced bins

Figure A9: RDD plot with five-point outcome variable 